\title{
DNA Barcodes for Bio-surveillance: Regulated and Economically Important Arthropod Plant Pests
}

\begin{tabular}{|r|l|}
\hline Journal: & Genome \\
\hline Manuscript ID & gen-2016-0024.R2 \\
\hline Manuscript Type: & Review \\
\hline Date Submitted by the Author: & 16-Jul-2016 \\
\hline Complete List of Authors: & $\begin{array}{l}\text { Ashfaq, Muhammad; University of Guelph Biodiversity Institute of Ontario } \\
\text { Hebert, Paul; Biodiversity Institute of Ontario, }\end{array}$ \\
\hline Keyword: & $\begin{array}{l}\text { species identification, cryptic taxa, invasive species, quarantine, pest } \\
\text { management }\end{array}$ \\
\hline \multicolumn{2}{|l}{} \\
\hline
\end{tabular}


DNA Barcodes for Bio-surveillance: Regulated and Economically Important Arthropod Plant Pests

Muhammad Ashfaq* and Paul D.N. Hebert

Centre for Biodiversity Genomics, Biodiversity Institute of Ontario, University of Guelph, Guelph, ON, Canada

* Corresponding author:

Muhammad Ashfaq

Centre for Biodiversity Genomics, Biodiversity Institute of Ontario, University of Guelph, Guelph, ON N1G 2W1, Canada

Email: mashfaq@uoguelph.ca

Phone: (519) 824-4120 Ext. 56393 


\begin{abstract}
Many of the arthropod species that are important pests of agriculture and forestry are impossible to discriminate morphologically throughout all of their life stages. Some cannot be differentiated at any life stage. Over the past decade, DNA barcoding has gained increasing adoption as a tool to both identify known species and to reveal cryptic taxa. Although there has not been a focused effort to develop a barcode library for them, reference sequences are now available for $77 \%$ of the 409 species of arthropods documented on major pest databases. Aside from developing the reference library needed to guide specimen identifications, past barcode studies have revealed that a significant fraction of arthropod pests are a complex of allied taxa. Because of their importance as pests and disease vectors impacting global agriculture and forestry, DNA barcode results on these arthropods have significant implications for quarantine detection, regulation, and management. The current review discusses these implications in light of the presence of cryptic species in plant pests exposed by DNA barcoding.
\end{abstract}

Key words: Species identification, cryptic taxa, invasive species, quarantine, pest management 


\section{Introduction}

Thousands of arthropod species either directly attack economically important plants or transmit viral and bacterial diseases, imposing massive costs on agriculture and forestry. For example, the widely distributed diamondback moth, Plutella xylostella, causes \$US4B-5B in damage to crops each year (Zalucki et al. 2012). The economic losses due to arthropods are increasing as new species gain pest status, often following human-mediated range expansions which, in the absence of natural enemies (Liebhold et al. 2013), can lead to population explosions that move a species from non-pest in its native range to pest in newly colonized areas (Aukema et al. 2011). The number of alien species continues to rise with arthropods representing the dominant component of this cross-border traffic, for example in Europe, as documented by the European Environment Agency (http://www.eea.europa.eu/). Five major databases track the most important arthropod pests and disease vectors of agriculture and forestry; they are maintained by the Canadian Food Inspection Agency (CFIA) (www.inspection.gc.ca), the European and Mediterranean Plant Protection Organization (EPPO) (www.eppo.int), the Global Invasive Species Database (GISD) (http://www.iucngisd.org), the National Agricultural Pest Information System (NAPIS) (https://napis.ceris.purdue.edu) and the United States Department of Agriculture - Animal and Plant Health Inspection Service (USDA-APHIS) (www.aphis.usda.gov) (accessed 3-5 January 2016). These databases, which include regulated, invasive and economically important plant pests with a focus on species important in Europe and North America, have been used to compile unified pest lists (Frewin et al. 2013). Since significant progress on DNA barcoding of plant pests has also been made in these regions, the current article draws the core information from these five sources as a basis for a discussion of cryptic species and their implications for DNA barcode applications. All but 21 of the 409 arthropod pest species on these lists belong to five 
insect orders (Coleoptera, Diptera, Hemiptera, Lepidoptera, Thysanoptera) (Table S1). An additional 36 cryptic pest species reported in literature but not included in the five databases are considered in this article (Table S1). Taxonomic difficulties continue to constrain the regulation of pest arthropods as indicated by the fact that 18 of the entries on these lists are only identified to a genus (Table S1) while some with a species designation are known to be a species complex (Mally et al. 2015). These taxonomic complexities have provoked growing interest in the adoption of DNA-based approaches for species recognition, creating interesting challenges for traditional approaches to regulatory compliance (Jörger and Schrödl 2013).

The balance of this article begins by considering the effectiveness of DNA barcoding in identifying arthropods and in revealing cryptic species. It then proceeds to consider past studies of cryptic diversity in pest arthropods, before concluding with a discussion of the implications of DNA barcoding for pest regulation, management and quarantine.

\section{Effectiveness of DNA barcodes for arthropod identification}

The efficacy of DNA barcoding (Hebert et al. 2003a) for specimen identification and species discovery has stimulated an international research program which has generated a barcode reference library for more than 250,000 described species of animals, fungi and plants, data which resides in BOLD, the Barcode of Life Data System (Ratnasingham and Hebert 2007). Each of the 4.5 million animal records on BOLD has been assigned to a BIN, a Barcode Index Number (Ratnasingham and Hebert 2013), generating 452K BINs, predominantly insects (315K) 
(accessed 21 April 2016). Because BINs show strong congruence with species designated through past morphological study (Pentinsaari et al. 2014; Zahiri et al. 2014, Mutanen et al. 2015), they can be viewed as species proxies (Telfer et al. 2015) to facilitate the assessment of large-scale biodiversity patterns (Blagoev et al. 2015) and the detection of cryptic species complexes (Ashfaq et al. 2015; Kekkonen and Hebert 2014). The use of barcode data to identify species (Rakauskas and Basilova 2013) as opposed to BINs requires the species in question be represented in the barcode reference library (Ekrem et al. 2007). Because the barcode reference library now includes records for many agricultural and forestry pests (Ashfaq et al. 2014; Foottit et al. 2014; Raupach et al. 2014), newly encountered specimens of these species can be identified through barcode analysis. As well, the extension of DNA barcoding protocols onto nextgeneration sequencing (NGS) platforms (Shokralla et al. 2014) is enabling metabarcoding studies which permit large-scale assessments of species composition (Taberlet et al. 2012), an approach of high importance in monitoring plant pests.

DNA barcoding has a strong track record in delivering species-level identifications for the five insect orders with the most pest species - Coleoptera (Rougerie et al. 2015; Woodcock et al. 2013), Diptera (Nagy et al. 2013; Smit et al. 2013), Hemiptera (Park et al. 2011b; Raupach et al. 2014), Lepidoptera (Ashfaq et al. 2013; Janzen et al. 2005) and Thysanoptera (Rebijith et al. 2014; Iftikhar et al. 2016). For example, $92.2 \%$ of 3514 species of European beetles were assigned to a distinct BIN that coincided with a known morphological species, while most of the other species were assigned to two or three BINs, suggesting they represent cryptic species complexes (Hendrich et al. 2015). Work on Diptera has similarly validated the effectiveness of 
DNA barcoding for the identification of species in this order, including some of the most important agricultural pests, such as fruit flies (Virgilio et al. 2012) and leafminers (Amin et al. 2014). Another study that examined 1849 species of Canadian Hemiptera assigned these species to 1867 BINs with high correspondence between species and BINs, but also revealed 27 species with high divergences suggestive of cryptic species complexes (Gwiazdowski et al. 2015). Lepidoptera, the most intensively studied order, is represented by more than 100,000 BINs on BOLD. Work on this group has demonstrated the efficacy of DNA barcoding in identifying known species (Dinca et al. 2015; Wilson et al. 2013) and in revealing cryptic species complexes (Burns et al. 2008; Huemer et al. 2014a). It has also shown that there is very limited geographic variation in barcode sequences in populations of most species so increased geographic scale does not reduce the success of species identification (Lukhtanov et al. 2009; Huemer et al. 2014b, Candek and Kuntner 2015). However, in certain groups, such as diving beetles of the tribe Agabini (Bergsten et al. 2012), the correlation between genetic and geographic distances is strong enough to impact the success of species identification unless sampling of each species is fairly comprehensive. Studies on Lepidoptera have further shown the way in which DNA barcoding can challenge current taxonomic boundaries, can shift understanding of distributions (Rougerie et al. 2014) and can expose inconsistent usage of species names (Mutanen et al. 2012). Finally, work on Lepidoptera has confirmed that BINs are a strong proxy for species. For example, $93 \%$ of 215 species of European geometrid moths showed a perfect correspondence between BINs and known species (Hausmann et al. 2013). 
The effectiveness of DNA barcoding in species recognition has also been established for Acari, the other major group of arthropods with important plant pests (Young et al. 2012). For example, it allowed resolution of the species composition of spider mites in agricultural settings in Vietnam (Hinomoto et al. 2007) and Europe (Ros and Breeuwer 2007). These studies have stimulated the development of barcode reference libraries, and have also revealed overlooked species in this group of pests (Matsuda et al. 2013).

A search on BOLD (December 22, 2015) revealed sequence coverage for 314 (269 public) of the 409 species $(77 \%)$ of plant arthropod pests (Table 1). Although sequences and BIN assignments for 45 species on BOLD were private, they were included as taxa with coverage. Coverage for species of Diptera (90\%) and Lepidoptera (87\%) was higher than that for Coleoptera (71\%) and Hemiptera (64\%). Table 2 details the number of barcode records, BINs, and intraspecific divergence values for the pest species with five or more sequences on BOLD. All but 18 of these 314 species possessed at least one barcode-compliant $(>500 \mathrm{bp},<1 \%$ ambiguous bases, no stopcodon or contamination) record and $1 / 3$ of the species $(61 / 178)$ represented by five or more records showed a BIN split, suggesting that they represent a species complex (Table 2, Table S1). However, the possibility that some of these cases may reflect misidentifications or introgression (Harrison and Larson 2014) cannot be ruled out without detailed study on a caseby-case basis.

\section{Incomplete resolution or flawed taxonomy?}


DNA barcoding has failed to separate some congeneric species of important pests such as the tephritid fruit flies Bactrocera occipitalis and B. philippinensis (Sumalde et al. 2013). Another study which examined 193 tephritid species failed to discriminate six species in the B. dorsalis complex (B. dorsalis, B. occipitalis, B. carambolae, B. papaya, B. invadens, B. philippinensis) (Frey et al. 2013; Jiang et al. 2014). This discrepancy between taxonomic assignments and barcode results (Hendrichs et al. 2015) provoked a reevaluation of their taxonomy, work which suggested that at least some of the taxa involved are conspecific (Khamis et al. 2012; Schutze et al. 2012). In fact, a subsequent taxonomic revision synonymized $B$. invadens and $B$. papaya with B. dorsalis (Schutze et al. 2015). There are many other cases where pest species on different plants have been assigned to separate species when they likely represent just one taxon. For example, populations of the "mango mealybug" on mango trees in Pakistan were identified to Drosicha mangiferae (Latif 1949) while those on forest trees were assigned to D. stebbingi (Gul et al. 1997). A barcode study (Ashfaq et al. 2011), supported by results from three other gene regions, did not reveal any genetic divergence between mealybugs on mango and six other fruit and forest trees, supporting an earlier suggestion of their synonymy (Latif 1949).

\section{Cryptic Species}

Although the definition of cryptic species is fluid (Jörger and Schrödl 2013), it is generally accepted that lineages with deep mitochondrial divergence without obvious morphological differences are strong candidates (Rivera and Currie 2009). Although divergence patterns in mitochondrial and nuclear genes are sometimes discordant (Humphries et al. 2011), surveys of mitochondrial diversity provide quick insight into species boundaries (Mutanen et al. 2015). 
Lineages showing sequence divergence, often termed molecular operational taxonomic units (MOTUs) (Blaxter et al. 2005), have been discriminated by analyzing sequence variation using distance analysis (Schloss and Handelsman 2005), neighbor-joining clustering (Saitou and Nei 1987), phylogenetic trees (Zhang et al. 2013), Bayesian inference (Yang and Rannala 1997), coalescence-based approach (Pons et al. 2006; Fujisawa and Barraclough 2013), barcode-gap analysis (Puillandre et al. 2012) and BINs (Ratnasingham and Hebert 2013). However, there is a growing trend to integrate multiple methods (Ashfaq et al. 2015; Blagoev et al. 2015; Kekkonen et al. 2015) and multiple markers (Jörger et al. 2012; Mrinalini et al. 2015) to assess MOTU diversity. The results from such analyses have frequently been helpful in resolving taxonomic problems and in estimating species richness and abundance (Mutanen et al. 2013; Stahlhut et al. 2013; Unterseher et al. 2011). However, the use of a single, standardized, marker has the advantage of simplifying molecular identification (Savolainen et al. 2005), a valuable feature for pest managers and regulators in field applications (Armstrong and Ball 2005). Reflecting the ease of recovering sequence information, and access to refined analytical tools, the discovery of new cryptic species is now commonplace in many animal groups.

Cryptic species have important implications for taxonomic, evolutionary, and biodiversity studies, but their presence in pest taxa also has economic and regulatory implications (Piffaretti et al. 2013; Rebijith et al. 2014). Several studies have considered the impact of cryptic species on pest management (Frewin et al. 2014; Ovalle et al. 2014), biological control strategies (Derocles et al. 2015), the detection of invasive species (Blacket et al. 2015; Li et al. 2015) and quarantine inspections (Kang et al. 2015). The most obvious implications of DNA barcoding relate to its 
capacity to discriminate the members of cryptic species complexes (Robe et al. 2013). Systems which employ sequence matches to identify specimens are already a reality (MacLeod et al. 2010), allowing the automated detection of regulated species (Lammers et al. 2014). However, in large-scale metabarcoding, standardization of metadata and taxonomic identifications still require consensus (Tedersoo et al. 2015), factors which currently limit the application of this approach in a regulatory context. This gap could be addressed through community action, perhaps via the International Barcode of Life (iBOL) (http://ibol.org) or the Genomics Standards Consortium (http://gensc.org/) model (Yilmaz et al. 2011).

\section{Revealing cryptic species in pest arthropods}

The effectiveness of DNA barcoding in revealing overlooked species in global pests like bark beetles, leafminers, gall midges, mealybugs, wireworms, seed borers, gypsy moths, armyworms and thrips is well documented (Table 3). For example, Liriomyza langei (Diptera: Agromyzidae), a leafminer pest native to California, is morphologically indistinguishable from the invasive $L$. huidobrensis. However, the two species are easily discriminated by barcoding, a factor which enabled the analysis of their distributions (Scheffer et al. 2014). Similarly, the larvae of Camptomyia corticalis and C. heterobia which inflict severe damage on the production of shiitake mushrooms are easily separated by their 10.3\% barcode divergence (Shin et al. 2013). Aphids are globally important pests and major vectors of many plant diseases, but they are challenging to identify because most of the 3000 species in this family possess striking phenotypic plasticity and life stage diversity. DNA barcoding has proven an effective tool for species discrimination because intraspecific distance is low in most species, averaging just $0.2 \%$, 
while congeneric distances are high (Foottit et al. 2008). However, some species, such as Neomyzus circumflexus, have higher divergences (>3\%), suggesting they represent a complex (Table 3). Tussock moths (Lepidoptera: Lymantriidae) are worldwide pests which have been well-studied taxonomically. Nonetheless, DNA barcode studies revealed deep intraspecific divergences in Lymantria dispar (3.1\%), L. mathura (4.7\%) and L. sinica (2.9\%) suggesting possible overlooked species (Table 3). Similarly, DNA barcode results have generally indicated congruence with morphologically recognized species of thrips (Qiao et al. 2012), but cryptic diversity is common with cases of high intraspecific divergence and deep genetic splits in several pest species (Tables 2, 3).

\section{Practical Implications of DNA Barcoding}

\section{Pest regulation and management:}

DNA barcoding is gaining broad application in integrated pest management (IPM) (Etzler et al. 2014) and bio-surveillance (Jones et al. 2013) programs as the standard method for species identification by 'matching unknown against the known' (Armstrong 2010). This is evidenced by the development of barcode-based kits for the identification of quarantine pests (Jiang-Ling et al. 2015). IPM requires the correct identification of target species and monitoring of its effectiveness often involves diverse stakeholders including farmers, crop pest regulators and quarantine agents. As long as "query" specimens show close sequence similarity to species in the reference library, match-based identifications are effective (Hebert et al. 2003b). Although most morphological species show congruence with BINs (Pentinsaari et al. 2014; Zahiri et al. 2014; 
Table 1), inconsistencies between morphologically recognized species and the genetic clusters discriminated by BINs are not infrequent. Such discrepancies complicate the identification of their component taxa with implications for pest regulation and management. For example, the whitefly, Bemisia tabaci, is now known to be a complex of at least 34 species (Lee et al. 2013) which differ in their invasiveness (De Barro and Ahmed 2011), their capacity to transmit plant pathogens (Chowda-Reddy et al. 2012) and their regional pest status (Ashfaq et al. 2014). Likewise, two pest thrips, Scirtothrips dorsalis and Thrips tabaci, are species complexes whose members vary in their invasiveness and viral-transmission ability (Dickey et al. 2015; Jacobson et al. 2013). Similarly, root weevil, Diaprepes abbreviatus, is a species complex (Ascunce et al. 2008) with 13 BINs that show differing geographic distributions. Any effort to regulate such species complexes as a single entity is inappropriate because it can complicate regulatory compliance and compromise management and control efforts by raising concerns when noninvasive or non-vector species are treated as pests. Although many regulated pest species with barcode records are assigned to a single BIN, about one third on BOLD show a BIN split (Table 1). For example, Leucinodes orbonalis, a quarantine pest, is represented by six BINs, with diverse geographic origins. The cross-border movements of species with BIN diversity raise complexities that will often create ambiguity in species matches requiring revisions to quarantine regulations. Conversely, there are cases where different species lack barcode divergence, preventing their discrimination. The most dramatic case involves 20 species in the fruit fly genus Bactrocera which share the same BIN. While some of these taxa have recently been synonymized (Schutze et al. 2015) and other cases may reflect misidentifications, it is likely that other cases reflect closely allied species which hybridize. Such cases require more detailed 
investigation to ascertain if other genetic markers allow their discrimination or reveal that they are actually synonyms.

Since DNA barcoding reliably identifies both immatures and adults (Shin et al. 2013), and can differentiate introduced and native pests (Chown et al. 2008), it has been used to help manage species complexes in agricultural systems (Frewin et al. 2014; Li et al. 2011). Such applications are important because insecticide resistance can vary between closely related species, and even between genotypes of the same species (van Toor et al. 2008). For example, two cryptic whiteflies in the B. tabaci complex, Mediterranean and Middle East-Asia Minor 1 (MEAM1), differ in their susceptibility to insecticides. A study on the response of mixed populations of these species showed that the Mediterranean species prevails under insecticide-based management, but is displaced by $M E A M 1$ under biological control (Frewin et al. 2014).

Biological control is widely viewed as the optimal pest management strategy, but incorrect identification of either the pest species or its control agent due to cryptic diversity can lead to unpredictable outcomes (Van Lenteren et al. 2003). Because of its capacity to determine hostparasitoid associations (Erlandson et al. 2003), DNA barcoding has been employed to gain a deeper understanding of biological control using natural enemies. For example, Davis et al. (2011) differentiated immatures of Laricobius rubidus, a native biological control agent of hemlock woolly adelgid, Adelges tsugae (complex of four BINs) from the closely related $L$. nigrinus introduced from Japan while Derocles et al. (2015) examined interactions between a 
leafminer and its parasitoids to advance biological control. Several studies have revealed unexpected diversity and interactions linked to cryptic diversity. The outcomes of biological control rapidly gain unpredictability (Roderick et al. 2012) when both the control agent and the target are cryptic species complexes, as for example, in the case of the hymenopteran wasp, Trichogramma japonicum (3 BINs) which is employed as a control agent for the brinjal borer, $L$. orbonalis (6 BINs).

\section{Quarantine of invasive alien species:}

Expansions in the geographic range of insect pests often require a rapid response (Adrion et al. 2014), and DNA barcoding can provide insights beyond those obtained through morphological analysis. For example, aside from enabling the early detection of invasive species (Onah et al. 2015), DNA barcoding can reveal source regions (Bellis et al. 2015) and introduction patterns (Blacket et al. 2015). Nagoshi et al. (2011) used it to monitor introductions of the invasive armyworm species, Spodoptera litura and S. littoralis, into Florida, while Tyagi et al. (2015) and Wei et al. (2010) detected the first invasions of Thrips parvispinus and Echinothrips americanus, in India and China. In a similar fashion, DNA barcoding differentiated Heliothis armigera from the native $H$. zea, revealing the spread of the former species after its introduction into Brazil (Mastrangelo et al. 2014). More recently, DNA barcoding led to the recognition of a buprestid beetle, Agrilus ribesi, whose introduction to North America had been overlooked for a century (Jendek et al. 2015). Barcoding has also been used to detect invasive tephritid fruit flies in Nigeria (Onah et al. 2015), leafminers in Papua New Guinea (Blacket et al. 2015) and Italy (Bernardo et al. 2015), a stink bug (Halyomorpha halys) in Europe (Cesari et al. 2015) and a 
cotton bug, Oxycarenus hyalinipennis in Florida (Nagoshi et al. 2012). Based on its effectiveness in species identification, the Quarantine Barcode of Life project (www.qbol.org) worked towards establishing DNA barcoding as the core technology for identifying quarantine organisms in support of plant health, and to gain its acceptance by the pest regulators as the standard method for the identification of plant pests (van de Vossenberg et al. 2013). Since DNA barcoding meets the minimum standards (Floyd et al. 2010) set under the International Standards for Phytosanitary Measures (ISPM) No. 27, “Diagnostic Protocols for Regulated Pests" and has been validated for use in regulatory sciences (Jones et al. 2013), it is positioned for adoption as the preferred diagnostic tool for species for quarantine and regulation. For example, USDAAgriculture Research Service is using DNA barcodes to monitor pest and invasive arthropods (http://agresearchmag.ars.usda.gov/AR/archive/2012/Apr/insects0412.pdf). However, the incorporation of this technology into the routine workflows of regulatory agencies is still under development. There is a particular need to develop well-parameterized reference datasets on important pest species for the countries of origin. Because nearly $75 \%$ of all BINs on BOLD, in general, derive from North America and Europe, with relatively low coverage for regions that host many potentially important global pests, there is a need for aggressive efforts for further parameterization of the barcode reference library. However, even before this task is complete, DNA barcode analysis makes it possible to signal the detection of any newly encountered species, providing a stimulus for its further investigation.

\section{Conclusions}


The increased global trade in plants and plant products has dramatically increased the risk of introducing novel pest species, creating the potential for massive economic losses to agriculture and forestry. For example, loss linked to the introduction of the emerald ash borer into North America has been estimated at tens of billions of dollars (Kovacs et al 2010, Herms and McCullough 2014). Because of its capability to support large-scale bio-surveillance programs, DNA barcoding can be an effective tool for intercepting invasive species at their points of introduction, and can also enable their early detection in natural environments. While speciesspecific primer sets can be a valuable tool for the quarantine detection of a particular species (Yeh et al. 2014), there is a critical need to gain a deeper understanding of diversity in many pest species as nearly one third of these taxa on BOLD (Table 1) appear to represent a species complex. High throughput sequencing platforms represent a powerful technology which will enable the use of DNA barcoding in large-scale bio-surveillance programs which can target both known pest species and new arrivals (Pochon et al. 2013). Given the complexities in morphological discrimination of many cryptic taxa, there is an obvious need to adopt DNAbased systems of nomenclature for pest regulation and quarantine (Cook et al. 2010). 


\section{References}

Abd-Rabou, S., Shalaby, H., Germain, J.F., Ris, N., Kreiter, P., and Malausa, T. 2012. Identification of mealybug pest species (Hemiptera: Pseudococcidae) in Egypt and France, using a DNA barcoding approach. Bull. Entomol. Res. 102(5): 515-523.

Adrion, J.R., Kousathanas, A., Pascual, M., Burrack, H.J., Haddad, N.M., Bergland, A.O., et al. 2014. Drosophila suzukii: The genetic footprint of a recent, worldwide invasion. Mol. Biol. Evol. 31(12): 3148-3163.

Amin, S., Scheffer, S.J., Lewis, M.L., Pasha, M.K., and Bhuiya, B.A. 2014. DNA barcoding of the vegetable leafminer Liriomyza sativae Blanchard (Diptera: Agromyzidae) in Bangladesh. DNA Barcodes 2(1): 29-33.

Armstrong, K.F. 2010. DNA barcoding: a new module in New Zealand's plant biosecurity diagnostic toolbox. EPPO Bull. 40(1): 91-100.

Armstrong, K.F., and Ball, S.L. 2005. DNA barcodes for biosecurity: invasive species identification. Phil. Trans. R. Soc. Lond. B Biol. Sci. 360(1462): 1813-1823.

Ascunce, M.S., Ernst, J.A., Clark, A., and Nigg, H.N. 2008. Mitochondrial nucleotide variability in invasive populations of the root weevil Diaprepes abbreviatus (Coleoptera: Curculionidae) of Florida and preliminary assessment of Diaprepes sp. from Dominica. J. Econ. Entomol. 101(4): 1443-1454. 
Ashfaq, M., Akhtar, S., Khan, A.M., Adamowicz, S.J., and Hebert, P.D.N. 2013. DNA barcode analysis of butterfly species from Pakistan points towards regional endemism. Mol. Ecol. Resour. 13(5): 832-843.

Ashfaq, M., Ara, J., Noor, A.R., Hebert, P.D.N., and Mansoor, S. 2011. Molecular phylogenetic analysis of a scale insect (Drosicha mangiferae; Hemiptera: Monophlebidae) infesting mango orchards in Pakistan. Eur. J. Entomol. 108(4): 553-559.

Ashfaq, M., Hebert, P.D.N., Mirza, M.S., Khan, A.M., Mansoor, S., Shah, G.S., et al. 2014. DNA barcoding of Bemisia tabaci complex (Hemiptera: Aleyrodidae) reveals southerly expansion of the dominant whitefly species on cotton in Pakistan. PLOS ONE 9(8): e104485.

Ashfaq, M., Prosser, S., Nasir, S., Masood, M., Ratnasingham, S., and Hebert, P.D.N. 2015. High diversity and rapid diversification in the head louse, Pediculus humanus (Pediculidae: Phthiraptera). Sci. Rep. 5: 14188. doi: 10.1038/srep14188.

Aukema, J.E., Leung, B., Kovacs, K., Chivers, C., Britton, K.O., Englin, J., et al. 2011. Economic impacts of non-native forest insects in the continental United States. PLOS ONE 6(9): e24587.

Ball, S.L., and Armstrong, K.F. 2006. DNA barcodes for insect pest identification: a test case with tussock moths (Lepidoptera: Lymantriidae). Can. J. Forest Res. 36(2): 337-350.

Bellis, G.A., Gopurenko, D., Cookson, B., Postle, A.C., Halling, L., Harris, N., et al. 2015. Identification of incursions of Culicoides Latreille species (Diptera: Ceratopogonidae) in Australasia using morphological techniques and DNA barcoding. Austral. Entomol. 54(3): 332-338. 
Bernardo, U., van Nieukerken, E.J., Sasso, R., Gebiola, M., Gualtieri, L., and Viggiani, G. 2015. Characterization, distribution, biology and impact on Italian walnut orchards of the invasive North-American leafminer Coptodisca lucifluella (Lepidoptera: Heliozelidae). Bull. Entomol. Res. 105(2): 210-224.

Bergsten, J., Bilton, D.T., Fujisawa, T., Elliott, M., Monaghan, M.T., Balke, M., et al. 2012. The effect of geographical scale of sampling on DNA barcoding. Syst. Biol. 61(5): 851-869.

Blacket, M.J., Rice, A.D., Semeraro, L., and Malipatil, M.B. 2015. DNA-based identifications reveal multiple introductions of the vegetable leafminer Liriomyza sativae (Diptera: Agromyzidae) into the Torres Strait Islands and Papua New Guinea. Bull. Entomol. Res. 105(5): 533-544.

Blagoev, G.A., deWaard, J.R., Ratnasingham, S., deWaard, S.L., Lu, L., Robertson, J., et al. 2015. Untangling taxonomy: a DNA barcode reference library for Canadian spiders. Mol. Ecol. Resour. 16(1): 325-341.

Blaxter, M., Mann, J., Chapman, T., Thomas, F., Whitton, C., Floyd, R., et al. 2005. Defining operational taxonomic units using DNA barcode data. Phil. Trans. R. Soc. B: Biol. Sci. 360(1462): 1935-1943.

Burns, J.M., Janzen, D.H., Hajibabaei, M., Hallwachs, W., and Hebert, P.D.N. 2008. DNA barcodes and cryptic species of skipper butterflies in the genus Perichares in Area de Conservacion Guanacaste, Costa Rica. Proc. Natl. Acad. Sci. USA 105(17): 6350-6355.

Candek, K., and Kuntner, M. 2015. DNA barcoding gap: reliable species identification over morphological and geographical scales. Mol. Ecol. Resour. 15: 268-277. 
Cesari, M., Maistrello, L., Ganzerli, F., Dioli, P., Rebecchi, L., and Guidetti, R. 2015. A pest alien invasion in progress: potential pathways of origin of the brown marmorated stink bug Halyomorpha halys populations in Italy. J. Pest Sci. 88(1): 1-7.

Chang, H., Liu, Q., Hao, D., Liu, Y., An, Y., Qian, L., and Yang, X. 2014. DNA barcodes and molecular diagnostics for distinguishing introduced Xyleborus (Coleoptera: Scolytinae) species in China. Mitochondr. DNA 25(1): 63-69.

Chowda-Reddy, R.V., Kirankumar, M., Seal, S.E., Muniyappa, V., Valand, G.B., Govindappa, M.R., et al. 2012. Bemisia tabaci phylogenetic groups in India and the relative transmission efficacy of Tomato leaf curl Bangalore virus by an indigenous and an exotic population. J. Integr. Agric. 11(2): 235-248.

Chown, S., Sinclair, B., and van Vuuren, B. 2008. DNA barcoding and the documentation of alien species establishment on sub-Antarctic Marion Island. Polar Biol. 31(5): 651-655.

Cook, L.G., Edwards, R.D., Crisp, M.D., and Hardy, N.B. 2010. Need morphology always be required for new species descriptions? Invertebr. Syst. 24(3): 322-326.

Davis, G.A., Havill, N.P., Adelman, Z.N., Caccone, A., Kok, L.T., and Salom, S.M. 2011. DNA barcodes and molecular diagnostics to distinguish an introduced and native Laricobius (Coleoptera: Derodontidae) species in eastern North America. Biol. Control 58(1): 53-59.

De Barro, P., and Ahmed, M.Z. 2011. Genetic networking of the Bemisia tabaci cryptic species complex reveals pattern of biological invasions. PLOS ONE 6(10): e25579. 
Derocles, S.A., Evans, D.M., Nichols, P.C., Evans, S.A., and Lunt, D.H. 2015. Determining plant - leafminer - parasitoid interactions: a DNA barcoding approach. PLOS ONE 10(2): e0117872.

deWaard, J.R., Mitchell, A., Keena, M.A., Gopurenko, D., Boykin, L.M., Armstrong, K.F., et al. 2010. Towards a global barcode library for Lymantria (Lepidoptera: Lymantriinae) tussock moths of biosecurity concern. PLOS ONE 5(12): e14280.

Dickey, A.M., Kumar, V., Hoddle, M.S., Funderburk, J.E., Morgan, J.K., Jara-Cavieres, A., et al. 2015. The Scirtothrips dorsalis species complex: endemism and invasion in a global pest. PLOS ONE 10(4): e0123747.

Dinca, V., Montagud, S., Talavera, G., Hernandez-Roldan, J., Munguira, M.L., Garcia-Barros, E., et al. 2015. DNA barcode reference library for Iberian butterflies enables a continentalscale preview of potential cryptic diversity. Sci. Rep. 5: 12395. doi:10.1038/srep12395.

Dong, C., Guo-Xia, L., Hai-Bin, F., and Wei, X. 2009. Phylogenetic analysis of mtCOI reveals the cryptic lineages in Phenacoccus solenopsis complex (Hemiptera: Pseudococcidae). Acta Entomol. Sinica 52(1): 1261-1265.

Dumas, P., Barbut, J., Le Ru, B., Silvain, J-F., Clamens, A-L., d'Alencon, E., et al. 2015. Phylogenetic molecular delimitations unravel potential new species in the pest genus Spodoptera Guenee, 1852 (Lepidoptera, Noctuidae). PLOS ONE 10(4): 0122407.

Ekrem, T., Willassen, E., and Stur, E. 2007. A comprehensive DNA sequence library is essential for identification with DNA barcodes. Mol. Phylogenet. Evol. 43(2): 530-542. 
Erlandson, M., Braun, L., Baldwin, D., Soroka, J., Ashfaq, M., and Hegedus, D. 2003. Molecular markers for Peristenus spp. (Hymenoptera : Braconidae) parasitoids associated with Lygus spp. (Hemiptera : Miridae). Can. Entomol. 135(1): 71-83.

Etzler, F.E., Wanner, K.W., Morales-Rodriguez, A., and Ivie, M.A. 2014. DNA barcoding to improve the species-level management of wireworms (Coleoptera: Elateridae). J. Econ. Entomol. 107(4): 1476-1485.

Floyd, R., Lima, J., deWaard, J., Humble, L., and Hanner, R. 2010. Common goals: policy implications of DNA barcoding as a protocol for identification of arthropod pests. Biol. Invasions 12: 2947-2954.

Foottit, R.G., Maw, E., and Hebert, P.D.N. 2014. DNA barcodes for Nearctic Auchenorrhyncha (Insecta: Hemiptera). PLOS ONE 9(7): e101385.

Foottit, R.G., Maw, H.E.L., Von Dohlen, C.D., and Hebert, P.D.N. 2008. Species identification of aphids (Insecta: Hemiptera: Aphididae) through DNA barcodes. Mol. Ecol. Resour. 8(6): 1189-1201.

Frewin, A.J., Scott-Dupree, C., and Hanner, R. 2013. DNA barcoding for plant protection: Applications and summary of available data for arthropod pests. CAB Reviews 8: 1-13.

Frewin, A.J., Scott-Dupree, C., Murphy, G., and Hanner, R. 2014. Demographic trends in mixed Bemisia tabaci (Hemiptera: Aleyrodidae) cryptic species populations in commercial poinsettia under biological control- and insecticide-based management. J. Econ. Entomol. 107(3): 11501155. 
Frey, J.E., Guillen, L., Frey, B., Samietz, J., Rull, J., and Aluja, M. 2013. Developing diagnostic SNP panels for the identification of true fruit flies (Diptera: Tephritidae) within the limits of COI-based species delimitation. BMC Evol. Biol. 13: 1-19.

Fujisawa, T., and Barraclough, T.G. 2013. Delimiting species using single-locus data and the Generalized Mixed Yule Coalescent approach: A revised method and evaluation on simulated data sets. Syst. Biol. 62(5):707-724.

Gauthier, N. 2010. Multiple cryptic genetic units in Hypothenemus hampei (Coleoptera: Scolytinae): evidence from microsatellite and mitochondrial DNA sequence data. Biol. J. Linn. Soc. 101(1): 113-129.

Gul, H., Bajwa, G.A., and Panhwar, G.N. 1997. Integrated control of mango mealy bug Drosicha stebbingi green (Hemiptera: Margarodidae) infesting forestry tree species at the Pakistan Forest Institute, Peshawar. Pak. J. Forestry 47: 65-72.

Gwiazdowski, R.A., Foottit, R.G., Maw, H.E.L., and Hebert, P.D.N. 2015. The Hemiptera (Insecta) of Canada: constructing a reference library of DNA barcodes. PLOS ONE 10(4): e0125635.

Harrison, R.G., and Larson, E.L. 2014. Hybridization, introgression, and the nature of species boundaries. J. Hered. 105 (S1): 795-809.

Hausmann, A., Godfray, H.C., Huemer, P., Mutanen, M., Rougerie, R., van Nieukerken, E.J., et al. 2013. Genetic patterns in European geometrid moths revealed by the Barcode Index Number (BIN) system. PLOS ONE 8(12): e84518. 
Hebert, P.D.N., Cywinska, A., Ball, S.L., and deWaard, J.R. 2003a. Biological identifications through DNA barcodes. Proc. R. Soc. B 270(1512): 313-321.

Hebert, P.D.N., Ratnasingham, S., and deWaard, J.R. 2003b. Barcoding animal life: cytochrome $c$ oxidase subunit 1 divergences among closely related species. Proc. Biol. Sci. 270 Suppl 1: S96-99.

Hendrich, L., Moriniere, J., Haszprunar, G., Hebert, P.D.N., Hausmann, A., Kohler, F., et al. 2015. A comprehensive DNA barcode database for Central European beetles with a focus on Germany: adding more than 3500 identified species to BOLD. Mol. Ecol. Resour. 15(3): 795818.

Hendrichs, J., Vera, M.T., Meyer, M.D., and Clarke, A.R. 2015. Resolving cryptic species complexes of major tephritid pests. ZooKeys 540: 5-39.

Herms, D.A., and McCullough, D.G. 2014. Emerald ash borer invasion of North America: History, biology, ecology, impacts, and management. Annu. Rev. Entomol. 59: 13-30.

Hinomoto, N., Tran, D.P., Pham, A.T., Le, T.B.N., Tajima, R., Ohashi, K., et al. 2007. Identification of spider mites (Acari: Tetranychidae) by DNA sequences: A case study in northern Vietnam. Int. J. Acarol. 33(1): 53-60.

Huemer, P., Karsholt, O., and Mutanen, M. 2014a. DNA barcoding as a screening tool for cryptic diversity: an example from Caryocolum, with description of a new species (Lepidoptera, Gelechiidae). ZooKeys 404: 91-111. 
Huemer, P., Mutanen, M., Sefc, K.M., and Hebert, P.D.N. 2014b. Testing DNA barcode performance in 1000 species of European Lepidoptera: large geographic distances have small genetic impacts. PLOS ONE 9(12): e115774.

Humphries, E.M., and Winker, K. 2011. Discord reigns among nuclear, mitochondrial and phenotypic estimates of divergence in nine lineages of trans-Beringian birds. Mol. Ecol. 20: $573-583$.

Iftikhar, R., Ashfaq, M., Rasool, A., and Hebert, P.D.N. 2016. DNA barcode analysis of thrips (Thysanoptera) diversity in Pakistan reveals cryptic species complexes. PLOS ONE 11(1): $\mathrm{e} 0146014$.

Jacobson, A.L., Booth, W., Vargo, E.L., and Kennedy, G.G. 2013. Thrips tabaci population genetic structure and polyploidy in relation to competency as a vector of Tomato spotted wilt virus. PLOS ONE 8(1): e54484.

Janzen, D.H., Hajibabaei, M., Burns, J.M., Hallwachs, W., Remigio, E., and Hebert, P.D.N. 2005. Wedding biodiversity inventory of a large and complex Lepidoptera fauna with DNA barcoding. Phil. Trans. R. Soc. Lond. B Biol. Sci. 360(1462): 1835-1845.

Jendek, E., Grebennikov, V.V., and Bocak, L. 2015. Undetected for a century: Palaearctic Agrilus ribesi Schaefer (Coleoptera: Buprestidae) on currant in North America, with adult morphology, larval biology and DNA barcode. Zootaxa 4034(1): 112-126.

Jiang, F., Jin, Q., Liang, L., Zhang, A.B., and Li, Z.H. 2014. Existence of species complex largely reduced barcoding success for invasive species of Tephritidae: a case study in Bactrocera spp. Mol. Ecol. Resour. 14(6): 1114-1128. 
Jiang-Ling, Y., Yu-Lin, A.N., Lu, Q., Xiao-Jun, Y., Mei, X., Cui-Ping, W., et al. 2015.

Development and application of quarantine insect DNA barcoding technology. Chinese J. Appl. Entomol. 52(2): 382-389.

Johnson, A.J., Weintraub, P.G., Katoch, R., Schemerhorn, B.J., and Shukle, R.H. 2012.

Biological and molecular characterization of Hessian fly (Diptera: Cecidomyiidae) from Israel. Bull. Entomol. Res. 102(6): 632-643.

Jones, Y.L., Peters, S.M., Weland, C., Ivanova, N.V., and Yancy, H.F. 2013. Potential use of DNA barcodes in regulatory science: Identification of the U.S. Food and Drug Administration's "Dirty 22," contributors to the spread of foodborne pathogens. J. Food Prot. 76(1): 144-149.

Jordal, B.H., and Kambestad, M. 2014. DNA barcoding of bark and ambrosia beetles reveals excessive NUMTs and consistent east-west divergence across Palearctic forests. Mol. Ecol. Resour. 14(1): 7-17.

Jörger, K.M., Norenburg, J.L., Wilson, N.G., and Schrödl, M. 2012. Barcoding against a paradox? Combined molecular species delineations reveal multiple cryptic lineages in elusive meiofaunal sea slugs. BMC Evol. Biol. 12: 245. DOI: 10.1186/1471-2148-12-245.

Jörger, K.M., and Schrödl, M. 2013. How to describe a cryptic species? Practical challenges of molecular taxonomy. Front. Zool. 10(10.1186): 1742-9994.

Kadirvel, P., Srinivasan, R., Hsu, Y.-C., Su, F.-C., and de la Pena, R. 2013. Application of cytochrome oxidase I sequences for phylogenetic analysis and identification of thrips species occurring on vegetable crops. J. Econ. Entomol. 106(1): 408-418. 
Kang, T.H., Lee, K.-S., and Lee, H.-S. 2015. DNA barcoding of the Korean Lymantria Hubner, 1819 (Lepidoptera: Erebidae: Lymantriinae) for quarantine inspection. J. Econ. Entomol. 108(4): 1596-1611.

Kekkonen, M., and Hebert, P.D.N. 2014. DNA barcode-based delineation of putative species: efficient start for taxonomic workflows. Mol. Ecol. Resour. 14(4): 706-715.

Kekkonen, M., Mutanen, M., Kaila, L., Nieminen, M., and Hebert, P.D.N. 2015. Delineating species with DNA barcodes: A case of taxon dependent method performance in moths. PLOS ONE 10(4): e0122481.

Khamis, F.M., Masiga, D.K., Mohamed, S.A., Salifu, D., de Meyer, M., and Ekesi, S. 2012. Taxonomic identity of the invasive fruit fly pest, Bactrocera invadens: concordance in morphometry and DNA barcoding. PLOS ONE 7(9): e44862.

Kovacs, K.F., Haight, R.G., McCullough D.G., Mercader R.J., Siegert N.W., and Liebhold, A.M. 2010. Cost of potential emerald ash borer damage in U.S. communities 2009-2019. Ecol. Econ. 69: 569-578.

Lammers, Y., Peelen, T., Vos, R.A., and Gravendeel, B. 2014. The HTS barcode checker pipeline, a tool for automated detection of illegally traded species from high-throughput sequencing data. BMC Bioinformatics 15: 44. doi:10.1186/1471-2105-15-44.

Latif, A. 1949. The taxonomic status of Drosicha stebbingi (Green) and Drosicha mangiferae (Green) (Hem., Coccid.). Bull. Entomol. Res. 40(3): 351-354. 
Lee, W., Park, J., Lee, G.-S., Lee, S., and Akimoto, S.-I. 2013. Taxonomic status of the Bemisia tabaci complex (Hemiptera: Aleyrodidae) and reassessment of the number of its constituent species. PLOS ONE 8(5): e63817.

Li, Q.Q., Li, D.Y., Ye, H., Liu, X.F., Shi, W., Cao, N., and Duan, Y.Q. 2011. Using COI gene sequence to barcode two morphologically alike species: the cotton bollworm and the oriental tobacco budworm (Lepidoptera: Noctuidae). Mol. Biol. Rep. 38(8): 5107-5113.

Li, Y., Duan, X., Qiao, X., Li, X., Wang, K., Men, Q., et al. 2015. Mitochondrial DNA revealed the extent of genetic diversity and invasion origin of populations from two separate invaded areas of a newly invasive pest, Cydia pomonella (L.) (Lepidoptera: Tortricidae) in China. Bull. Entomol. Res. 105(4): 485-496.

Liebhold, A.M., McCullough, D.G., Blackburn, L.M., Frankel, S.J., Von Holle, B., and Aukema, J.E. 2013. A highly aggregated geographical distribution of forest pest invasions in the USA. Divers. Distrib. 19(9): 1208-1216.

Lukhtanov, V.A., Sourakov, A., Zakharov EV., and Hebert, P.D.N. 2009. DNA barcoding Central Asian butterflies: Increasing geographical dimension does not significantly reduce the success of species identification. Mol. Ecol. Resour. 9(5): 1302-1310.

MacLeod, N., Benfield, M., and Culverhouse, P. 2010. Time to automate identification. Nature 467(7312): 154-155. doi: 10.1038/467154a.

Mally, R., Korycinska, A., Agassiz D.J.L., Hall, J., Hodgetts, J., and Nuss, M. 2015. Discovery of an unknown diversity of Leucinodes species damaging Solanaceae fruits in sub-Saharan Africa and moving in trade (Insecta, Lepidoptera, Pyraloidea). ZooKeys 472: 117-162. 
Matsuda, T., Fukumoto, C., Hinomoto, N., and Gotoh, T. 2013. DNA-based identification of spider mites: molecular evidence for cryptic species of the genus Tetranychus (Acari: Tetranychidae). J. Econ. Entomol. 106(1): 463-472.

Mastrangelo, T., Paulo, D.F., Bergamo, L.W., Morais, E.G.F., Silva, M., Bezerra-Silva, G., et al. 2014. Detection and genetic diversity of a Heliothine invader (Lepidoptera: Noctuidae) from north and northeast of Brazil. J. Econ. Entomol. 107(3): 970-980.

Mathur, S., Cook, M.A., Sinclair, B.J., and Fitzpatrick, S.M. 2012. DNA barcodes suggest cryptic speciation in Dasineura oxycoccana (Diptera: Cecidomyiidae) on cranberry, Vaccinium macrocarpon, and blueberry, V. corymbosum. Fla. Entomol. 95(2): 387-394.

Mrinalini, Thorpe, R.S., Creer, S., Lallias, D., Dawnay, L., Stuart, B.L., Malhotra, A. 2015. Convergence of multiple markers and analysis methods defines the genetic distinctiveness of cryptic pitvipers. Mol. Phylogenet. Evol. 92: 266-279.

Mutanen, M., Hausmann, A., Hebert, P.D.N., Landry, J.F., de Waard, J.R., and Huemer, P. 2012. Allopatry as a gordian knot for taxonomists: patterns of DNA barcode divergence in arcticalpine Lepidoptera. PLOS ONE 7(10): e47214.

Mutanen, M., Kaila, L., and Tabell, J. 2013. Wide-ranging barcoding aids discovery of one-third increase of species richness in presumably well-investigated moths. Sci. Rep. 3: 2901. doi:10.1038/srep02901

Mutanen, M., Kekkonen, M., Prosser, S.W.J., Hebert, P.D.N., and Kaila, L. 2015. One species in eight: DNA barcodes from type specimens resolve a taxonomic quagmire. Mol. Ecol. Resour. 15(4): 967-984. 
Nadel, R.L., Slippers, B., Scholes, M.C., Lawson, S.A., Noack, A.E., Wilcken, C.F., et al. 2010. DNA bar-coding reveals source and patterns of Thaumastocoris peregrinus invasions in South Africa and South America. Biol. Invasions 12(5): 1067-1077.

Nagoshi, R.N., Brambila, J., and Meagher, R.L. 2011. Use of DNA barcodes to identify invasive armyworm Spodoptera species in Florida. J. Insect Sci. 11(154): doi: 10./031.011.

Nagoshi, R.N., Paraiso, O., Brambila, J., and Kairo, M.T. 2012. Assessing the usefulness of DNA barcoding to identify Oxycarenus hyalinipennis (Hemiptera: Oxycarenidae) in Florida, a potentially invasive pest of cotton. Fla. Entomol. 95(4): 1174-1181.

Nagy, Z.T., Sonet, G., Mortelmans, J., Vandewynkel, C., and Grootaert, P. 2013. Using DNA barcodes for assessing diversity in the family Hybotidae (Diptera, Empidoidea). ZooKeys 365: $263-278$.

Onah, I.E., Eyo, J.E., and Taylor, D. 2015. Molecular identification of tephritid fruit flies (Diptera: Tephritidae) infesting sweet oranges in Nsukka Agro-Ecological Zone, Nigeria, based on PCR-RFLP of COI gene and DNA barcoding. Afr. Entomol. 23(2): 342-347.

Ovalle, T.M., Parsa, S., Hernandez, M.P., and Becerra Lopez-Lavalle, L.A. 2014. Reliable molecular identification of nine tropical whitefly species. Ecol. Evol. 4(19): 3778-3787.

Park, D.-S., Suh, S.-J., Hebert, P.D.N., Oh, H.-W., and Hong, K.-J. 2011a. DNA barcodes for two scale insect families, mealybugs (Hemiptera: Pseudococcidae) and armored scales (Hemiptera: Diaspididae). Bull. Entomol. Res. 101(04): 429-434. 
Park, D.S., Foottit, R., Maw, E., and Hebert, P.D.N. 2011b. Barcoding bugs: DNA-based identification of the true bugs (Insecta: Hemiptera: Heteroptera). PLOS ONE 6(4): e18749.

Pentinsaari, M., Hebert, P.D.N., and Mutanen, M. 2014. Barcoding beetles: a regional survey of 1872 species reveals high identification success and unusually deep interspecific divergences. PLOS ONE 9(9): 2014.

Piffaretti, J., Rossi, J.P., Vanlerberghe-Masutti, F., Genson, G., Coeur d'Acier, A., and Jousselin, E. 2013. Molecular identification and ecological characteristics of two cryptic lineages within a cosmopolitan aphid pest, Brachycaudus helichrysi (Hemiptera: Aphididae). Appl. Entomol. Zool. 48(2): 155-164.

Pochon, X., Bott, N.J,, Smith, K.F., and Wood, S.A. 2013. Evaluating detection limits of nextgeneration sequencing for the surveillance and monitoring of international marine pests. PLOS ONE 8(9): e73935.

Pons, J., Barraclough, T.G., Gomez-Zurita, J., Cardoso1, A., Duran1, D.P., Hazell, S., et al. 2006. Sequence-based species delimitation for the DNA taxonomy of undescribed insects. Syst. Biol. 55(4): 595-609.

Puillandre, N., Lambert, A., Brouillet, S., and Achaz, G. 2012. ABGD, Automatic Barcode Gap Discovery for primary species delimitation. Mol. Ecol. 21(8): 1864-1877.

Qiao, W.-N., Wan, F.-H., Zhang, A.-B., Min, L., and Zhang, G.-F. 2012. Application of DNA barcoding technology for species identification of common thrips (Insecta: Thysanoptera) in China. Acta Entomol. Sinica 55(3): 344-356. 
Rakauskas, R., and Basilova, J. 2013. Barcoding of aphids (Hemiptera, Aphididae and Adelgidae): Proper usage of the global data set. Mol. Ecol. Resour. 13(1): 6-9.

Ratnasingham, S., and Hebert, P.D.N. 2007. BOLD: The Barcode of Life Data System (http://www.barcodinglife.org). Mol. Ecol. Notes 7(3): 355-364.

Ratnasingham, S., and Hebert, P.D.N. 2013. A DNA-based registry for all animal species: The Barcode Index Number (BIN) system. PLOS ONE 8(7): e66213.

Raupach, M.J., Hendrich, L., Kuchler, S.M., Deister, F., Moriniere, J., and Gossner, M.M. 2014. Building-up of a DNA barcode library for true bugs (Insecta: Hemiptera: Heteroptera) of Germany reveals taxonomic uncertainties and surprises. PLOS ONE 9(9): e106940.

Rebijith, K.B., Asokan, R., Kumar, N.K., Krishna, V., Chaitanya, B.N., and Ramamurthy, V.V. 2013. DNA barcoding and elucidation of cryptic aphid species (Hemiptera: Aphididae) in India. Bull. Entomol. Res. 103(5): 601-610.

Rebijith, K.B., Asokan, R., Krishna, V., Ranjitha, H.H., Kumar, N.K.K., and Ramamurthy, V.V. 2014. DNA barcoding and elucidation of cryptic diversity in thrips (Thysanoptera). Fla. Entomol. 97(4): 1328-1347.

Rivera, J., and Currie, D.C. 2009. Identification of Nearctic black flies using DNA barcodes (Diptera: Simuliidae). Mol. Ecol. Resour. 9: 224-236.

Robe, L.J., De Re, F.C., Ludwig, A., and Loreto, E.L. 2013. The Drosophila flavopilosa species group (Diptera, Drosophilidae): an array of exciting questions. Fly 7(2): 59-69. 
Roderick, G.K., Hufbauer, R., and Navajas, M. 2012. Evolution and biological control. Evol. Appl. 5(5): 419-423.

Ros, V.I.D., and Breeuwer, J.A.J. 2007. Spider mite (Acari: Tetranychidae) mitochondrial COI phylogeny reviewed: host plant relationships, phylogeography, reproductive parasites and barcoding. Exp. Appl. Acarol. 42: 239-262.

Rougerie, R., Kitching, I.J., Haxaire, J., Miller, S.E., Hausmann, A., and Hebert, P.D.N. 2014. Australian Sphingidae - DNA barcodes challenge current species boundaries and distributions. PLOS ONE 9(7): e101108.

Rougerie, R., Lopez-Vaamonde, C., Barnouin, T., Delnatte, J., Moulin, N., Noblecourt, T., et al. 2015. PASSIFOR: A reference library of DNA barcodes for French saproxylic beetles (Insecta, Coleoptera). Biodivers. Data J. 4(3): e4078.

Rugman-Jones, P.F., Hoddle, M.S., and Stouthamer, R. 2010. Nuclear-mitochondrial barcoding exposes the global pest Western flower thrips (Thysanoptera: Thripidae) as two sympatric cryptic species in its native California. J. Econ. Entomol. 103(3): 877-886.

Saitou, N., and Nei, M. 1987. The Neighbor-Joining method: a new method for reconstructing phylogenetic trees. Mol. Biol. Evol. 4(4): 406-425.

Savolainen, V., Cowan, R.S., Vogler, A.P., Roderick, G.K., and Lane, R. 2005. Towards writing the encyclopaedia of life: An introduction to DNA barcoding. Phil. Trans. R. Soc. B 360: 1805-1811. 
Scheffer, S.J., Lewis, M.L., Gaimari, S.D., and Reitz, S.R. 2014. Molecular survey for the invasive leafminer pest Liriomyza huidobrensis (Diptera: Agromyzidae) in California uncovers only the native pest Liriomyza langei. J. Econ. Entomol. 107(5): 1959-1964.

Schloss, P.D., and Handelsman, J. 2005. Introducing DOTUR, a computer program for defining operational taxonomic units and estimating species richness. Appl. Environ. Microb. 71(3): 1501-1506.

Schutze, M.K., Krosch, M.N., Armstrong, K.F., Chapman, T.A., Englezou, A., Chomï̈ , A., et al. 2012. Population structure of Bactrocera dorsalis s.s., B. papayae and B. philippinensis (Diptera: Tephritidae) in Southeast Asia: evidence for a single species hypothesis using mitochondrial DNA and wing-shape data. BMC Evol. Biol. 12(1): 130.

Schutze, M.K., Aketarawong, N., Amornsak, W., Armstrong, K.F., Augustinos, A.A., Barr, N., et al. 2015. Synonymization of key pest species within the Bactrocera dorsalis species complex (Diptera: Tephritidae): taxonomic changes based on a review of 20 years of integrative morphological, molecular, cytogenetic, behavioural and chemoecological data. Syst. Entomol. 40: 456-471.

Shashank, P., Chakravarthy, A., Raju, B., and Bhanu, K. 2014. DNA barcoding reveals the occurrence of cryptic species in host-associated population of Conogethes punctiferalis (Lepidoptera: Crambidae). Appl. Entomol. Zool. 49(2): 283-295.

Shin, S., Jung, S., Heller, K., Menzel, F., Hong, T.K., Shin, J.S., et al. 2015. DNA barcoding of Bradysia (Diptera: Sciaridae) for detection of the immature stages on agricultural crops. J. Appl. Entomol. 139(8): 638-645. 
Shin, S., Jung, S., Lee, H., and Lee, S. 2013. Molecular identification of dipteran pests (Diptera: Sciaroidea) from shiitake mushroom. Mol. Ecol. Resour. 13(2): 200-209.

Shokralla, S., Gibson, J.F., Nikbakht, H., Janzen, D.H., Hallwachs, W., and Hajibabaei, M. 2014. Next-generation DNA barcoding: using next-generation sequencing to enhance and accelerate DNA barcode capture from single specimens. Mol. Ecol. Resour. 14(5): 892-901.

Simmons, R.B., and Scheffer, S.J. 2004. Evidence of cryptic species within the pest Copitarsia decolora (Guenee) (Lepidoptera: Noctuidae). Ann. Entomol. Soc. Am. 97(4): 675-680.

Smit, J., Reijnen, B., and Stokvis, F. 2013. Half of the European fruit fly species barcoded (Diptera, Tephritidae); a feasibility test for molecular identification. ZooKeys 365: 279-305.

Stahlhut, J.K., Fernandez-Triana, J., Adamowicz, S.J., Buck, M., Goulet, H., Hebert, P.D.N., et al. 2013. DNA barcoding reveals diversity of Hymenoptera and the dominance of parasitoids in a sub-arctic environment. BMC Ecol. 13(2): 1472-6785.

Sumalde, A.A.M., Mendioro, M.S., Delomen, M.L.C., and Medina, C.D. 2013. DNA barcoding and morphometric analyses of oriental fruit fly species Bactrocera occipitalis (Bezzi) and B. philippinensis (Drew and Hancock) (Diptera: Tephritidae) from Guimaras, Philippines. Philipp. Entomol. 27(1): 58-74.

Taberlet, P., Coissac, E., Pompanon, F., Brochmann, C., and Willerslev, E. 2012. Towards nextgeneration biodiversity assessment using DNA metabarcoding. Mol. Ecol. 21(8): 2045-2050.

Takano, S.-I., Mochizuki, A., Konishi, K., Takasu, K., Alouw, J.C., Pandin, D.S., et al. 2011. Two cryptic species in Brontispa longissima (Coleoptera: Chrysomelidae): Evidence from 
mitochondrial DNA analysis and crosses between the two nominal species. Ann. Entomol. Soc. Am. 104(2): 121-131.

Tedersoo, L., Ramirez, K.S., Nilsson, R.H., Kaljuvee, A., Koljalg, U., and Abarenkov, K. 2015. Standardizing metadata and taxonomic identification in metabarcoding studies. GigaScience 4: 34-34.

Telfer, A.C., Young, M.R., Quinn, J., Peraz, K., Sobel, C.N., Sones, J.E., et al. 2015. Biodiversity inventories in high gear: DNA barcoding facilitates a rapid biotic survey of a temperate nature reserve. Biodiv. Data J. 3: e6313.

ToŠEvski, I.V.O., Caldara, R., JoviĆ, J., HernÁNdez-Vera, G., Baviera, C., Gassmann, A., et al. 2011. Morphological, molecular and biological evidence reveal two cryptic species in Mecinus janthinus Germar (Coleoptera, Curculionidae), a successful biological control agent of Dalmatian toadflax, Linaria dalmatica (Lamiales, Plantaginaceae). Syst. Entomol. 36(4): 741753.

Tyagi, K., Kumar, V., Singha, D., and Chakraborty, R. 2015. Morphological and DNA barcoding evidence for invasive pest thrips, Thrips parvispinus (Thripidae: Thysanoptera), newly recorded from India. J. Insect Sci. 15(105). doi: 10.1093/jisesa/iev087.

Unterseher, M., Jumpponen, A., Oepik, M., Tedersoo, L., Moora, M., Dormann, C.F., et al. 2011. Species abundance distributions and richness estimations in fungal metagenomics lessons learned from community ecology. Mol. Ecol. 20(2): 275-285. 
van de Vossenberg, B.T.L.H., Westenberg, M., and Bonants, P.J.M. 2013. DNA barcoding as an identification tool for selected EU-regulated plant pests: an international collaborative test performance study among 14 laboratories. EPPO Bull. 43(2): 216-228.

Van Lenteren, J.C., Babendreier, D., Bigler, F., Burgio, G., Hokkanen, H.M.T., Kuske, S., et al. 2003. Environmental risk assessment of exotic natural enemies used in inundative biological control. Bio Control 48(1): 3-38.

Van Nieukerken, E.J., Wagner, D.L., Baldessari, M., Mazzon, L., Angeli, G., Girolami, V., et al. 2012. Antispila oinophylla new species (Lepidoptera, Heliozelidae), a new North American grapevine leafminer invading Italian vineyards: taxonomy, DNA barcodes and life cycle. ZooKeys 170: 29-77.

van Toor, R.F., Foster, S.P., Anstead, J.A., Mitchinson, S., Fenton, B., and Kasprowicz, L. 2008. Insecticide resistance and genetic composition of Myzus persicae (Hemiptera: Aphididae) on field potatoes in New Zealand. Crop Prot. 27(2): 236-247.

Virgilio, M., Jordaens, K., Breman, F.C., Backeljau, T., and De Meyer, M. 2012. Identifying insects with incomplete DNA barcode libraries, African fruit flies (Diptera: Tephritidae) as a test case. PLOS ONE 7(2): e31581.

Wang, J.-F., and Qiao, G.-X. 2009. DNA barcoding of genus Toxoptera Koch (Hemiptera: Aphididae): Identification and molecular phylogeny inferred from mitochondrial COI sequences. Insect Sci. 16(6): 475-484. 
Wei, S.-J., Mirab-Balou, M., Shi, B.-C., Gong, Y.-J., Liu, J., Kang, Z.-J., et al. 2010. External morphology and molecular identification of the newly found invasive pest Echinothrips americanus Morgan (Thysanoptera: Thripidae) in China. Acta Entomol. Sinica 53(6): 715-715.

Wilson, J.-J., Sing, K.-W., and Sofian-Azirun, M. 2013. Building a DNA barcode reference library for the true butterflies (Lepidoptera) of Peninsula Malaysia: What about the subspecies? PLOS ONE 8(11): e79969.

Woodcock, T.S., Boyle, E.E., Roughley, R.E., Kevan, P.G., Labbee, R.N., Smith, A.B., et al. 2013. The diversity and biogeography of the Coleoptera of Churchill: insights from DNA barcoding. BMC Ecol. 13(40): 1472-6785.

Yang, Z.H., and Rannala, B. 1997. Bayesian phylogenetic inference using DNA sequences: A Markov Chain Monte Carlo method. Mol. Biol. Evol. 14(7): 717-724.

Yassin, A., Capy, P., Madi-Ravazzi, L., Ogereau, D., and David, J.R. 2008. DNA barcode discovers two cryptic species and two geographical radiations in the invasive drosophilid Zaprionus indianus. Mol. Ecol. Resour. 8(3): 491-501.

Yeh, W.B., Tseng, M.J., Chang, N.T., Wu, S.Y., and Tsai, Y.S. 2014. Development of speciesspecific primers for agronomical thrips and multiplex assay for quarantine identification of Western flower thrips. J. Econ. Entomol. 107(5): 1728-1735.

Yilmaz, P., Kottmann, R., Field, D., Knight, R., Cole, J.R., Amaral-Zettler, L, et al. 2011. Minimum information about a marker gene sequence (MIMARKS) and minimum information about any (x) sequence (MIxS) specifications. Nat. Biotechnol. 29:415-420. 
Young, M.R., Behan-Pelletier, V.M., and Hebert, P.D.N. 2012. Revealing the hyperdiverse mite fauna of subarctic Canada through DNA barcoding. PLOS ONE 7(11): e48755.

Zahiri, R., Lafontaine, J.D., Schmidt, B.C., Dewaard, J.R., Zakharov, E.V., and Hebert, P.D.N. 2014. A transcontinental challenge - a test of DNA barcode performance for 1,541 species of Canadian Noctuoidea (Lepidoptera). PLOS ONE 9(3): e92797.

Zalucki, M.P., Shabbir, A., Silva, R., Adamson, D., Shu-Sheng, L., and Furlong, M.J. 2012. Estimating the economic cost of one of the world's major insect pests, Plutella xylostella (Lepidoptera: Plutellidae): Just how long is a piece of string? J. Econ. Entomol. 105(4): 11151129.

Zhang, J., Kapli, P., Pavlidis, P., and Stamatakis, A. 2013. A general species delimitation method with applications to phylogenetic placements. Bioinformatics 29(22): 2869-2876. 
Table 1. Progress in the development of a DNA barcode reference library for regulated arthropod plant pests based on records in the Barcode of Life Data Systems (www.boldsystems.org) on December 22, 2015.

\begin{tabular}{llllll}
\hline Order & $\begin{array}{l}\text { Number of } \\
\text { pest species }^{\mathrm{a}}\end{array}$ & $\begin{array}{l}\text { Number of } \\
\text { species with } \\
\text { barcodes on } \\
\text { BOLD (with } \\
\text { single record) }\end{array}$ & $\begin{array}{l}\text { Number of } \\
\text { species in a } \\
\text { single BIN }\end{array}$ & $\begin{array}{l}\text { Number of } \\
\text { species with }_{\text {more than }} \\
\text { one BIN }^{\mathrm{b}}\end{array}$ & $\begin{array}{l}\text { Number of } \\
\text { species } \\
\text { without a }_{\text {BIN }^{\mathrm{c}}}\end{array}$ \\
\hline Acari & 8 & 4 & 1 & 1 & 2 \\
Coleoptera & 162 & $116(17)$ & 61 & 29 & 9 \\
Diptera & 42 & $38(2)$ & 24 & 11 & 1 \\
Hemiptera & 59 & $38(4)$ & 20 & 8 & 6 \\
Hymenoptera & 10 & $7(1)$ & 3 & 3 & 0 \\
Lepidoptera & 115 & $101(10)$ & 68 & 23 & 0 \\
Orthoptera & 3 & 2 & 0 & 2 & 0 \\
Thysanoptera & 10 & 8 & 1 & 7 & 0 \\
\hline Total & 409 & $314(34)$ & 178 & 84 & 18 \\
\hline
\end{tabular}

${ }^{a}$ Sources: CFIA, EPPO (A1 \& A2 lists), NAPIS, USDA-APHIS and Global Invasive Species Database (100 of the world's worst invasive alien species).

${ }^{\mathrm{b}}$ Only species with multiple records are included. Additional information is available in Table S1.

${ }^{\mathrm{c}}$ Sequences with $<500 \mathrm{bp},>1 \%$ ambiguous bases or with stop codons are not assigned a BIN. 
Table 2. The number of Barcode Index Numbers (BINs) and maximum intraspecific sequence divergences (K2P) at COI for arthropod plant pests based on data in BOLD, the Barcode of Life Data Systems (www.boldsystems.org).

\begin{tabular}{|c|c|c|c|c|c|}
\hline Order & Common name & Species & $\begin{array}{l}\text { Barcode } \\
\text { records }\end{array}$ & BINs & $\begin{array}{l}\text { Maximum } \\
\text { intraspecific } \\
\text { divergence }(\%)\end{array}$ \\
\hline Acari & Red spider mite & Tetranychus evansi & 6 & 2 & 3.0 \\
\hline \multirow[t]{20}{*}{ Coleoptera } & Oak splendour beetle & Agrilus biguttatus & 7 & 2 & 22.0 \\
\hline & Citrus longhorned beetle & Anoplophora chinensis & 33 & 3 & 4.6 \\
\hline & Boll weevil & Anthonomus grandis & 119 & 3 & 7.8 \\
\hline & Strawberry bud weevil & Anthonomus signatus & 12 & 3 & 4.3 \\
\hline & Spruce beetle & Dendroctonus rufipennis & 10 & 4 & 5.5 \\
\hline & Northern corn rootworm & Diabrotica barberi & 32 & 3 & 4.4 \\
\hline & Diaprepes root weevil & Diaprepes abbreviatus & 79 & 13 & 10.9 \\
\hline & Lesser spruce shoot beetle & Hylurgops palliatus & 21 & 4 & 5.5 \\
\hline & Alfalfa weevil & Hypera postica & 16 & 2 & 5.6 \\
\hline & Six-toothed bark beetle & Ips sexdentatus & 6 & 2 & 12.1 \\
\hline & European spruce bark beetle & Ips typographus & 15 & 2 & 3.0 \\
\hline & White clover weevil & Ischnopterapion virens & 10 & 2 & 4.6 \\
\hline & Sugarbeet wireworm & Limonius californicus & 81 & 4 & 5.7 \\
\hline & $\begin{array}{l}\text { Small white-marmorated } \\
\text { longhorned beetle }\end{array}$ & Monochamus sutor & 15 & 2 & 5.1 \\
\hline & Alfalfa snout beetle & Otiorhynchus ligustici & 6 & 2 & 4.9 \\
\hline & Cereal leaf beetle & Oulema melanopus & 16 & 3 & 8.7 \\
\hline & $\begin{array}{l}\text { Six-toothed spruce bark } \\
\text { beetle }\end{array}$ & Pityogenes chalcographus & 14 & 4 & 8.7 \\
\hline & European oak bark beetle & Scolytus intricatus & 17 & 6 & 11.5 \\
\hline & $\begin{array}{l}\text { European spruce longhorn } \\
\text { beetle }\end{array}$ & Tetropium castaneum & 12 & 5 & 27.0 \\
\hline & Asian ambrosia beetle & Xylosandrus crassiusculus & 5 & 3 & 11.0 \\
\hline \multirow[t]{10}{*}{ Diptera } & Guava fruit fly & Anastrepha striata & 18 & 2 & 4.2 \\
\hline & Carambola fruit fly & Bactrocera carambolae & 109 & 2 & 15.8 \\
\hline & Oriental fruit fly & Bactrocera dorsalis & 645 & 5 & 10.4 \\
\hline & Asian fruit fly & Bactrocera invadens & 230 & 2 & 8.4 \\
\hline & Olive fruit fly & Bactrocera oleae & 107 & 3 & 8.6 \\
\hline & Peach fruit fly & Bactrocera zonata & 42 & 4 & 10.6 \\
\hline & Vegetable leafminer & Liriomyza sativae & 38 & 2 & 11.8 \\
\hline & $\begin{array}{l}\text { American serpentine } \\
\text { leafminer }\end{array}$ & Liriomyza trifolii & 12 & 2 & 14.1 \\
\hline & Apple maggot & Rhagoletis pomonella & 23 & 2 & 6.0 \\
\hline & European crane fly & Tipula paludosa & 129 & 2 & 12.2 \\
\hline \multirow[t]{5}{*}{ Hemiptera } & Hemlock woolly adelgid & Adelges tsugae & 150 & 4 & 8.3 \\
\hline & Silverleaf whitefly & Bemisia tabaci & 918 & 16 & 20.0 \\
\hline & Green scale & Coccus viridis & 5 & 2 & 16.8 \\
\hline & Brown marmorated stink bug & Halyomorpha halys & 37 & 3 & 17.5 \\
\hline & Vine mealybug & Planococcus ficus & 6 & 2 & 4.0 \\
\hline \multirow[t]{2}{*}{ Hymenoptera } & Oriental chestnut gall wasp & Dryocosmus kuriphilus & 7 & 2 & 2.3 \\
\hline & Green alder sawfly & Monsoma pulveratum & 18 & 2 & 3.8 \\
\hline \multirow[t]{4}{*}{ Lepidoptera } & Summer fruit tortrix moth & Adoxophyes orana & 23 & 3 & 6.7 \\
\hline & Asiatic rice borer & Chilo suppressalis & 57 & 3 & 18.9 \\
\hline & Yellow peach moth & Conogethes punctiferalis & 202 & 3 & 8.9 \\
\hline & Mexican rice borer & Eoreuma loftini & 8 & 2 & 3.1 \\
\hline
\end{tabular}




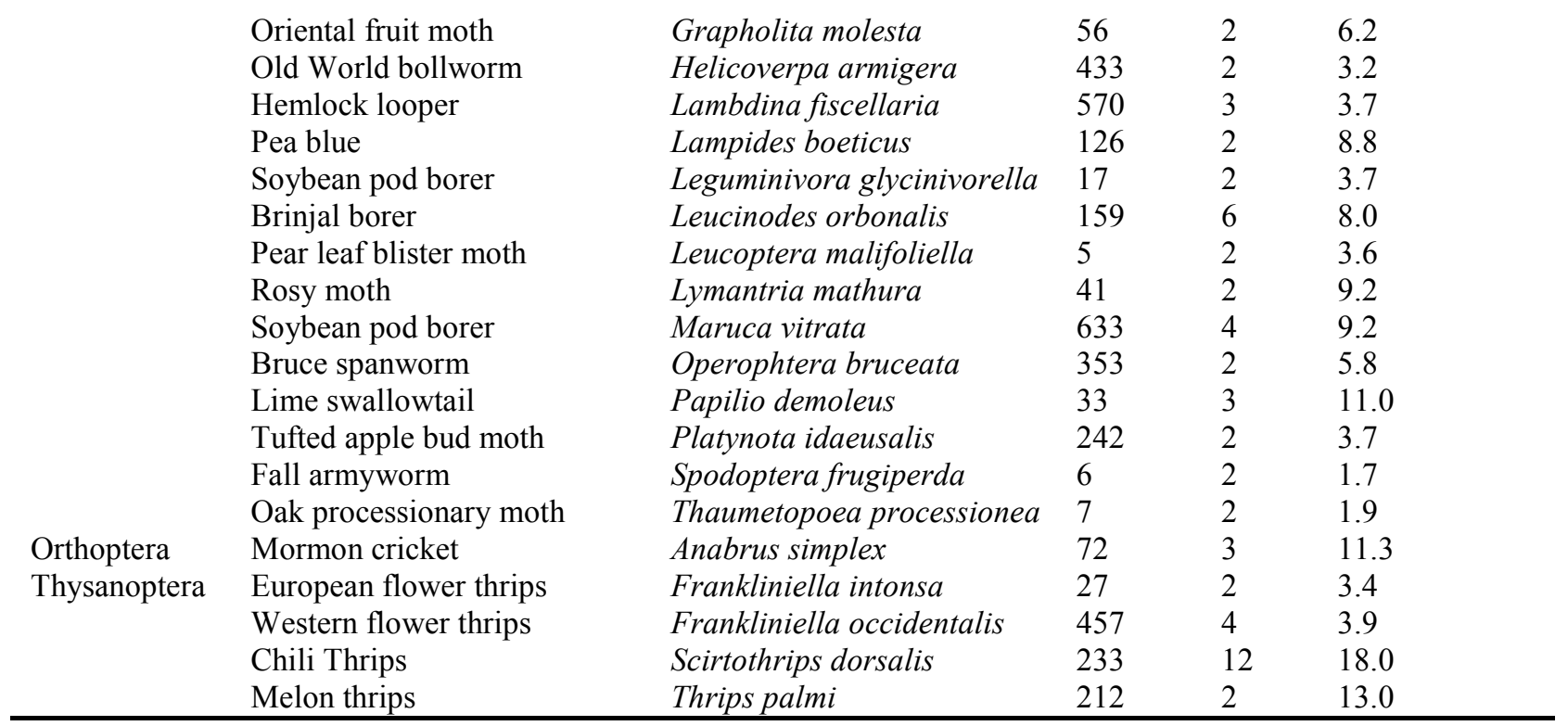

Species with at least 5 publicly available sequences on BOLD were included in the analysis. Additional information is provided in Table $\mathrm{S} 1$. 
Table 3. Arthropod plant pests reported as representing a cryptic species complex following DNA barcode analysis.

\begin{tabular}{|c|c|c|c|c|c|}
\hline Order & Common name & Species & $\begin{array}{l}\text { Max. } \\
\text { diver- } \\
\text { gence } \\
(\%)\end{array}$ & $\begin{array}{l}\mathrm{NJ} / \\
\text { phylog- } \\
\text { enetic } \\
\text { Clades }\end{array}$ & Reference \\
\hline \multirow[t]{2}{*}{ Acari } & $\begin{array}{l}\text { Kanzawa spider } \\
\text { mite }\end{array}$ & Tetranychus kanzawai & $4.7^{\mathrm{a}}$ & 2 & Matsuda et al. 2013 \\
\hline & NA & Tetranychus parakanzawai & $5.1^{\mathrm{a}}$ & 2 & “ \\
\hline \multirow[t]{15}{*}{ Coleoptera } & Bark beetle & Crypturgus subcribrosus & $6.7^{\mathrm{a}}$ & 2 & $\begin{array}{l}\text { Jordal and Kambestad } \\
2014\end{array}$ \\
\hline & Bark beetle & Crypturgus hispidulus & $6.8^{\mathrm{a}}$ & 2 & “ \\
\hline & $\begin{array}{l}\text { Hairy spruce bark } \\
\text { beetle }\end{array}$ & Dryocoetes autographus & $9.8^{\mathrm{a}}$ & 3 & “ \\
\hline & Bark beetle & Dryocoetes hectographus & $5.2^{\mathrm{a}}$ & 3 & “ \\
\hline & $\begin{array}{l}\text { Lesser spruce } \\
\text { shoot beetle }\end{array}$ & Hylurgops palliatus & $5.7^{\mathrm{a}}$ & 3 & “ \\
\hline & Engraver beetle & Ips acuminatus & $9.7^{\mathrm{a}}$ & 2 & “" \\
\hline & Bark beetle & Orthotomicus suturalis & $5.6^{\mathrm{a}}$ & 2 & “ \\
\hline & $\begin{array}{l}\text { Striped Ambrosia } \\
\text { Beetle }\end{array}$ & Trypodendron lineatum & $4.6^{\mathrm{a}}$ & 2 & “ \\
\hline & $\begin{array}{l}\text { Fruit-tree pinhole } \\
\text { borer }\end{array}$ & Xyleborinus saxeseni & $12.5^{\mathrm{a}}$ & 2 & “ \\
\hline & Ambrosia beetle & Xyleborus affinis & $20.1^{\mathrm{b}}$ & 3 & Chang et al. 2014 \\
\hline & Wireworm & Hypnoidus bicolor & $3.0^{\mathrm{a}}$ & 3 & Etzler et al. 2014 \\
\hline & $\begin{array}{l}\text { Yellow toadflax } \\
\text { stem weevil }\end{array}$ & Mecinus janthinus & $2.4^{\mathrm{a}}$ & 2 & ToŠEvski et al. 2011 \\
\hline & Coffee berry borer & Hypothenemus hampei & $11.8^{\mathrm{a}}$ & 4 & Gauthier 2010 \\
\hline & $\begin{array}{l}\text { Coconut leaf } \\
\text { beetle }\end{array}$ & Brontispa longissima & $3.0^{\mathrm{b}}$ & 2 & Takano et al. 2011 \\
\hline & Root weevil & Diaprepes abbreviatus & $14.9^{\mathrm{a}}$ & 3 & Ascunce et al. 2008 \\
\hline \multirow[t]{4}{*}{ Diptera } & Hessian fly & Mayetiola destructor & $3.0^{\mathrm{b}}$ & 2 & Johnson et al. 2012 \\
\hline & African fig fly & Zaprionus indianus & $11.2^{\mathrm{a}}$ & 2 & Yassin et al. 2008 \\
\hline & $\begin{array}{l}\text { Blueberry gall } \\
\text { midge }\end{array}$ & Dasineura oxycoccana & $10.7^{\mathrm{c}}$ & 2 & Mathur et al. 2012 \\
\hline & $\begin{array}{l}\text { Glasshouse } \\
\text { Striped Sciarid }\end{array}$ & Bradysia ocellaris & $2.4^{\mathrm{b}}$ & 2 & Shin et al. 2015 \\
\hline \multirow[t]{11}{*}{ Hemiptera } & Citrus mealybug & Planococcus citri & NA & 2 & Abd-Rabou et al. 2012 \\
\hline & $\begin{array}{l}\text { Solenopsis } \\
\text { mealybug }\end{array}$ & Phenacoccus solenopsis & $3.0^{\mathrm{b}}$ & 2 & Dong et al. 2009 \\
\hline & Apple mealybug & Phenacoccus aceris & $5.6^{\mathrm{b}}$ & 2 & Park et al. 2011a \\
\hline & $\begin{array}{l}\text { Matsumoto } \\
\text { mealybug }\end{array}$ & Crisicoccus matsumotoi & $4.0^{\mathrm{b}}$ & 2 & “ \\
\hline & Cyanotis scale & Aspidiotus excises & $4.6^{\mathrm{b}}$ & 2 & “ \\
\hline & Silverleaf whitefly & Bemisia tabaci & $20^{\mathrm{b}}$ & 15 & Ashfaq et al. 2014 \\
\hline & $\begin{array}{l}\text { Mottled arum } \\
\text { aphid }\end{array}$ & Neomyzus circumflexus & $3.1^{\mathrm{b}}$ & 2 & Foottit et al. 2008 \\
\hline & $\begin{array}{l}\text { Leaf curl plum } \\
\text { aphid }\end{array}$ & Brachycaudus helichrysi & $2.5^{\mathrm{b}}$ & 2 & Rebijith et al. 2013 \\
\hline & Cabbage aphid & Brevicorvne brassicae & $3.8^{\mathrm{b}}$ & 2 & “" \\
\hline & $\begin{array}{l}\text { Asian sowthistle } \\
\text { aphid }\end{array}$ & Hyperomyzus carduellinus & $3.0^{\mathrm{b}}$ & 2 & “ \\
\hline & Aphid & Toxoptera aurantii & $3.1^{\mathrm{b}}$ & 2 & Wang and Qiao 2009 \\
\hline
\end{tabular}




\begin{tabular}{|c|c|c|c|c|c|}
\hline \multirow{9}{*}{ Lepidoptera } & Bronze bug & Thaumastocoris peregrinus & $8.7^{\mathrm{b}}$ & 3 & Nadel et al. 2010 \\
\hline & $\begin{array}{l}\text { Grapewine } \\
\text { leafminer }\end{array}$ & Antispila hydrangaeella & $5.2^{\mathrm{b}}$ & 2 & $\begin{array}{l}\text { Van Nieukerken et al. } \\
2012\end{array}$ \\
\hline & Durian fruit borer & Conogethes punctiferalis & $5.8^{\mathrm{b}}$ & 2 & Shashank et al. 2014 \\
\hline & Leaf worm & Copitarsia decolora & $4.2^{\mathrm{a}}$ & 2 & $\begin{array}{l}\text { Simmons and Scheffer } \\
2004\end{array}$ \\
\hline & Asian gypsy moth & Lymantria dispar & $3.1^{\mathrm{b}}$ & 2 & Ball and Armstrong 2006 \\
\hline & Pink gypsy moth & Lymantria mathura & $4.7^{\mathrm{b}}$ & 2 & “ \\
\hline & & Lymantria sinica & $2.9^{\mathrm{b}}$ & 2 & deWaard et al. 2010 \\
\hline & Beet armyworm & Spodoptera exigua & NA & 2 & Dumas et al. 2015 \\
\hline & Paddy armyworm & S. mauritia & NA & 2 & “ \\
\hline \multirow[t]{5}{*}{ Thysanoptera } & $\begin{array}{l}\text { Western flower } \\
\text { thrips }\end{array}$ & Frankliniella occidentalis & $4.4^{\mathrm{b}}$ & 2 & $\begin{array}{l}\text { Rugman-Jones et al. } \\
2010\end{array}$ \\
\hline & Melon thrips & Thrips palmi & $19.9^{\mathrm{b}}$ & 4 & $\begin{array}{l}\text { Rebijith et al. 2014; } \\
\text { Kadirvel et al. 2013; } \\
\text { Iftikhar et al. } 2016\end{array}$ \\
\hline & Onion thrips & T. tabaci & $10.4^{\mathrm{b}}$ & 3 & “ \\
\hline & Chili thrips & Scirtothrips dorsalis & $20.8^{\mathrm{b}}$ & 11 & $\begin{array}{l}\text { Dickey et al. 2015; } \\
\text { Iftikhar et al. } 2016\end{array}$ \\
\hline & $\begin{array}{l}\text { Black flower } \\
\text { thrips }\end{array}$ & Haplothrips reuteri & $3.7^{\mathrm{b}}$ & 2 & Iftikhar et al. 2016 \\
\hline
\end{tabular}

The citations were collected by literature survey on the Web of Science with search terms "DNA barcoding pest cryptic" (accessed 12 January 2016). The citations were further restricted by only considering studies explicitly COI-5' and reporting cryptic species. Species also included in the five pest databases (Table S1) are bold faced.

${ }^{\mathrm{a}}$ p-distances; ${ }^{\mathrm{b}} \mathrm{K} 2 \mathrm{P}$ distances; ${ }^{\mathrm{c}} \mathrm{GTRpG}$; NA = Information not available 
Table S1. Arthropod plant pests listed on multiple databases and their DNA barcoding status on BOLD (

Common name

City longhorn beetle

Small Hive Beetle

St. Johnswort Borer

Emerald Ash Borer

Jewel Beetle

Wireworm

Wireworm

Asian Longhorned Beetle

na

Red Neck Longhorn Beetle

Oak Timberworm

Coconut hispid beetle

Plum curculio

European Chestnut Weevil

Great Spruce Bark Beetle

Mountain Pine Beetle (MPB)

Douglas-fir beetle

Cucurbit Beetle

Spotted cucumber beetle

Western Corn Rootworm

Potato Flea Beetle

na

Western Potato Flea Beetle

Tuber Flea beetle

Black pine bark beetle

Large Pine Weevil

Redhaired Pine Bark Beetle

Pine Engraver Beetle

Colorado Potato Beetle

Lily Leaf Beetle

Argentine Stem Weevil

Asiatic Garden Beetle

Corn wireworm

Japanese Pine Sawyer

Northeastern sawyer

Sakhalin Pine Sawyer

White-spotted sawyer

Whitefringed Weevil

Fruit tree weevil

Lemon tree borer

European Elm Flea Weevil

Mediterranean Pine Engraver

Coconut Rhinoceros Beetle

white pine weevil

\section{Species}

Aeolesthes sarta

Aethina tumida

Agrilus hyperici

Agrilus planipennis

Agrilus sulcicollis

Agriotes sputator

Agriotes ustulatus

Anoplophora glabripennis

Apriona germari

Apriona rugicollis

Aromia bungii

Arrhenodes minutus

Brontispa longissima

Conotrachelus nenuphar

Curculio elephas

Dendroctonus micans

Dendroctonus ponderosae

Dendroctonus pseudotsugae

Diabrotica speciosa

Diabrotica undecimpunctata

Diabrotica virgifera

Epitrix cucumeris

Epitrix similaris

Epitrix subcrinita

Epitrix tuberis

Hylastes ater

Hylobius abietis

Hylurgus ligniperda

Ips pini

Leptinotarsa decemlineata

Lilioceris lilii

Listronotus bonariensis

Maladera castanea

Melanotus communis

Monochamus alternatus

Monochamus notatus

Monochamus saltuarius

Monochamus scutellatus

Naupactus leucoloma

Naupactus xanthographus

Oemona hirta

Orchestes alni

Orthotomicus erosus

Oryctes rhinoceros

Pissodes strobi
Order

Coleoptera

Coleoptera

Coleoptera

Coleoptera

Coleoptera

Coleoptera

Coleoptera

Coleoptera

Coleoptera

Coleoptera

Coleoptera

Coleoptera

Coleoptera

Coleoptera

Coleoptera

Coleoptera

Coleoptera

Coleoptera

Coleoptera

Coleoptera

Coleoptera

Coleoptera

Coleoptera

Coleoptera

Coleoptera

Coleoptera

Coleoptera

Coleoptera

Coleoptera

Coleoptera

Coleoptera

Coleoptera

Coleoptera

Coleoptera

Coleoptera

Coleoptera

Coleoptera

Coleoptera

Coleoptera

Coleoptera

Coleoptera

Coleoptera

Coleoptera

Coleoptera

Coleoptera
Barcode records o

7

5

4

16

16

24

25

443

13

1

2

4

124

13

9

8

110

4

5

24

19

17

4

1

5

1

17

6

3

25

12

20

1

1

14

1

1

27

74

116

3

83

2

1

3 


\begin{tabular}{|c|c|c|c|}
\hline Oak Ambrosia Beetle & Platypus quercivorus & Coleoptera & 8 \\
\hline Four-eyed fir bark beetle & Polygraphus proximus & Coleoptera & 4 \\
\hline Japanese Beetle & Popillia japonica & Coleoptera & 24 \\
\hline Viburnum Leaf Beetle & Pyrrhalta viburni & Coleoptera & 41 \\
\hline New Guinea sugarcane weevil & Rhabdoscelus obscurus & Coleoptera & 1 \\
\hline South American Palm Weevil & Rhynchophorus palmarum & Coleoptera & 2 \\
\hline Poplar Borer & Saperda calcarata & Coleoptera & 9 \\
\hline Morawitz's bark beetle & Scolytus morawitzi & Coleoptera & 4 \\
\hline European Elm Bark Beetle & Scolytus scolytus & Coleoptera & 1 \\
\hline Mango seed weevil & Sternochetus mangiferae & Coleoptera & 5 \\
\hline \multicolumn{2}{|c|}{ Brown Spruce Longhorn Beetle Tetropium fuscum } & Coleoptera & 7 \\
\hline Pine Shoot Beetle & Tomicus destruens & Coleoptera & 1 \\
\hline Pine Shoot Beetle & Tomicus piniperda & Coleoptera & 20 \\
\hline Velvet Longhorned Beetle & Trichoferus campestris & Coleoptera & 6 \\
\hline Khapra Beetle & Trogoderma granarium & Coleoptera & 31 \\
\hline Pear Blight Beetle & Xyleborus dispar & Coleoptera & 83 \\
\hline Redbay Ambrosia Beetle & Xyleborus glabratus & Coleoptera & 4 \\
\hline Rustic Borer & Xylotrechus colonus & Coleoptera & 11 \\
\hline Oak Splendour Beetle & Agrilus biguttatus & Coleoptera & 7 \\
\hline Ambrosia Beetle & Anisandrus maiche & Coleoptera & 4 \\
\hline Alfalfa Weevil & Hypera postica & Coleoptera & 16 \\
\hline Sixtoothed Bark Beetle & Ips sexdentatus & Coleoptera & 6 \\
\hline European spruce bark beetle & Ips typographus & Coleoptera & 15 \\
\hline White clover weevil & Ischnopterapion virens & Coleoptera & 10 \\
\hline Small white-marmorated & Monochamus sutor & Coleoptera & 15 \\
\hline Alfalfa Snout Beetle & Otiorhynchus ligustici & Coleoptera & 6 \\
\hline Banded Elm Bark Beetle & Scolytus schevyrewi & Coleoptera & 3 \\
\hline Lesser Pine Shoot Beetle & Tomicus minor & Coleoptera & 4 \\
\hline Citrus long-horned beetle & Anoplophora chinensis & Coleoptera & 33 \\
\hline Boll Weevil (BW) & Anthonomus grandis & Coleoptera & 119 \\
\hline Strawberry Clipper & Anthonomus signatus & Coleoptera & 12 \\
\hline Northern Corn Rootworm & Diabrotica barberi & Coleoptera & 32 \\
\hline Cereal Leaf Beetle (CLB) & Oulema melanopus & Coleoptera & 16 \\
\hline Granulate Ambrosia Beetle & Xylosandrus crassiusculus & Coleoptera & 5 \\
\hline The spruce beetle & Dendroctonus rufipennis & Coleoptera & 10 \\
\hline Lesser Spruce Shoot Beetle & Hylurgops palliatus & Coleoptera & 21 \\
\hline Ambrosia Beetle & Limonius californicus & Coleoptera & 81 \\
\hline Sixtoothed Spruce Bark Beetle & Pityogenes chalcographus & Coleoptera & 14 \\
\hline European spruce longhorn bee & Tetropium castaneum & Coleoptera & 12 \\
\hline European Oak Bark Beetle & Scolytus intricatus & Coleoptera & 17 \\
\hline Diaprepes Root Weevil & Diaprepes abbreviatus & Coleoptera & 79 \\
\hline Pepper Weevil & Anthonomus eugenii & Coleoptera & 2 \\
\hline Nut weevil & Curculio nucum & Coleoptera & 1 \\
\hline Roundheaded pine beetle & Dendroctonus adjunctus & Coleoptera & 3 \\
\hline Western pine beetle & Dendroctonus brevicomis & Coleoptera & 2 \\
\hline Southern Pine Beetle & Dendroctonus frontalis & Coleoptera & 2 \\
\hline Coffee berry borer & Hypothenemus hampei & Coleoptera & 26 \\
\hline
\end{tabular}




\begin{tabular}{|c|c|c|c|c|}
\hline West Indian Cane Weevil & Metamasius hemipterus & Coleoptera & & 1 \\
\hline Red palm weevil & Rhynchophorus ferrugineus & Coleoptera & & 314 \\
\hline Chinese rose beetle & Adoretus sinicus & Coleoptera & na & \\
\hline Bronze Birch Borer & Agrilus anxius & Coleoptera & & 14 \\
\hline Goldspotted Oak Borer & Agrilus auroguttatus & Coleoptera & na & \\
\hline Oriental Beetle & Anomala orientalis & Coleoptera & & 5 \\
\hline Chafer beetle & Anomala sulcatula & Coleoptera & na & \\
\hline strawberry weevil & Anthonomus bisignifer & Coleoptera & & 1 \\
\hline Poplar Stem Borer & Apriona cinerea & Coleoptera & na & \\
\hline Oriental beetle & Blitopertha orientalis & Coleoptera & na & \\
\hline Rough Sweetpotato Weevil & Blosyrus asellus & Coleoptera & na & \\
\hline Japanese Cedar Longhorned B & $\epsilon$ Callidiellum rufipenne & Coleoptera & & 1 \\
\hline Brown Fir Longhorned Beetle & Callidiellum villosulum & Coleoptera & & 1 \\
\hline Bamboo Borer & Chlorophorus annularis & Coleoptera & na & \\
\hline Slender-Banded Pinecone Long & g Chlorophorus strobilicola & Coleoptera & na & \\
\hline Click beetle & Conoderes rufangulus & Coleoptera & na & \\
\hline Small avocado seed weevil & Conotrachelus aguacatae & Coleoptera & na & \\
\hline Avocado stem weevil & Copturus aguacatae & Coleoptera & na & \\
\hline Pecan Weevil & Curculio caryae & Coleoptera & & 5 \\
\hline Soybean Stem Borer & Dectes texanus & Coleoptera & na & \\
\hline Western balsam bark beetle & Dryocoetes confusus & Coleoptera & & 5 \\
\hline Fijian ginger weevil & Elytroteinus subtruncatus & Coleoptera & na & \\
\hline Mexican Bean Beetle & Epilachna varivestis & Coleoptera & & 1 \\
\hline West Indian sweet potato wee & Euscepes postfasciatus & Coleoptera & na & \\
\hline Leaf beetle & Exosoma lusitanica & Coleoptera & na & \\
\hline Tuberous pine weevil & Geniocremnus chilensis & Coleoptera & na & \\
\hline Western hemlock wood staine & Gnathotrichus sulcatus & Coleoptera & na & \\
\hline Eucalyptus snout beetle & Gonipterus gibberus & Coleoptera & na & \\
\hline Eucalyptus snout beetle & Gonipterus scutellatus & Coleoptera & na & \\
\hline Avocado seed weevil & Heilipus lauri & Coleoptera & na & \\
\hline Black Maize Beetle & Heteronychus arator & Coleoptera & na & \\
\hline White grub & Holotrichia mindanaona & Coleoptera & na & \\
\hline Loosestrife Root Weevil & Hylobius transversovittus & Coleoptera & na & \\
\hline Sixspined Ips & Ips calligraphus & Coleoptera & na & \\
\hline Pinyon Ips Beetle & Ips confusus & Coleoptera & & 1 \\
\hline Five-spined bark beetle & Ips grandicollis & Coleoptera & & 3 \\
\hline Kyrgyz mountain engraver & Ips hauseri & Coleoptera & na & \\
\hline Arizona five-spined engraver & Ips lecontei & Coleoptera & na & \\
\hline California pine engraver & Ips plastographus & Coleoptera & na & \\
\hline Scolytid Beetle & Ips subelongatus & Coleoptera & na & \\
\hline Chilean vegetable weevil & Listroderes subcinctus & Coleoptera & na & \\
\hline Ambrosia beetle & Megaplatypus mutatus & Coleoptera & & 1 \\
\hline Hemlock Borer & Melanophila fulvoguttata & Coleoptera & & 12 \\
\hline Pine sawyer beetle & Monochamus carolinensis & Coleoptera & & 15 \\
\hline Balsam fir sawyer & Monochamus marmorator & Coleoptera & & 5 \\
\hline Spotted Pine Sawyer & Monochamus mutator & Coleoptera & & 4 \\
\hline Japanese pine sawyer beetle & Monochamus nitens & Coleoptera & na & \\
\hline
\end{tabular}




\begin{tabular}{|c|c|c|c|c|}
\hline Flat-faced longhorn beetle & Monochamus obtusus & Coleoptera & & 3 \\
\hline Southern Pine Sawyer & Monochamus titillator & Coleoptera & & 6 \\
\hline Locust Leafminer & Odontota dorsalis & Coleoptera & & 10 \\
\hline Wingless Weevil & Otiorhynchus dieckmanni & Coleoptera & na & \\
\hline Eastern pine weevil & Pissodes nemorensis & Coleoptera & na & \\
\hline Lodgepole terminal weevil & Pissodes terminalis & Coleoptera & & 1 \\
\hline Bark Beetle & Pityoborus comatus & Coleoptera & na & \\
\hline Walnut Twig Beetle & Pityophthorus juglandis & Coleoptera & & 3 \\
\hline Andean potato weevil & Premnotrypes latithorax & Coleoptera & na & \\
\hline Andean potato weevil & Premnotrypes suturicallus & Coleoptera & na & \\
\hline Andean potato weevil & Premnotrypes vorax & Coleoptera & na & \\
\hline Twobanded Japanese Weevil & Pseudocneorhinus bifasciatus & Coleoptera & na & \\
\hline Small oak bark beetle & \multicolumn{3}{|c|}{ Pseudopityophthorus minutissimus Coleoptera } & 2 \\
\hline European Chafer (EC) & Rhizotrogus majalis & Coleoptera & na & \\
\hline \multicolumn{2}{|c|}{ Roundheaded Appletree Borer Saperda candida } & Coleoptera & & 10 \\
\hline \multicolumn{2}{|c|}{ Hemlock Woolly Adelgid Lady E Sasajiscymnus tsugae } & Coleoptera & na & \\
\hline Ladybird Beetle & Stethorus punctum & Coleoptera & na & \\
\hline Thin-antenna spruce borer & Tetropium gracilicorne & Coleoptera & na & \\
\hline Altai larch longhorn beetle & Xylotrechus altaicus & Coleoptera & na & \\
\hline Mulberry Borer & Xylotrechus chinensis & Coleoptera & na & \\
\hline Namangan longhorn beetle & Xylotrechus namanganensis & Coleoptera & na & \\
\hline Longhorned Beetle & Xylotrechus pyrrhoderus & Coleoptera & na & \\
\hline \multicolumn{2}{|c|}{ Coffee White Stem Borer Beetl Xylotrechus quadripes } & Coleoptera & na & \\
\hline \multicolumn{2}{|c|}{ South American cucurbit fruit $\mathrm{f}$ Anastrepha grandis } & Diptera & & 3 \\
\hline Mexican fruit fly & Anastrepha ludens & Diptera & & 68 \\
\hline West indian fruit fly & Anastrepha obliqua & Diptera & & 52 \\
\hline Sapote fruit fly & Anastrepha serpentina & Diptera & & 8 \\
\hline Fruit fly & Bactrocera caryeae & Diptera & & 1 \\
\hline Guava Fruit Fly & Bactrocera correcta & Diptera & & 54 \\
\hline Cucumber fruit fly & Bactrocera cucumis & Diptera & & 2 \\
\hline Melon Fly & Bactrocera cucurbitae & Diptera & & 221 \\
\hline Fruit fly & Bactrocera kandiensis & Diptera & & 17 \\
\hline Malaysian Fruit Fly & Bactrocera latifrons & Diptera & & 81 \\
\hline Chinese citrus fly & Bactrocera minax & Diptera & & 58 \\
\hline Fruit fly & Bactrocera occipitalis & Diptera & & 30 \\
\hline Asian Papaya Fruit Fly & Bactrocera papayae & Diptera & & 64 \\
\hline Fruit fly & Bactrocera philippinensis & Diptera & & 19 \\
\hline Queensland fruit fly & Bactrocera tryoni & Diptera & & 48 \\
\hline Japanese orange fly & Bactrocera tsuneonis & Diptera & & 21 \\
\hline Natal fruit fly & Ceratitis rosa & Diptera & & 40 \\
\hline Lesser pumpkin fly & Dacus ciliatus & Diptera & & 40 \\
\hline Spotted Wing Drosophila & Drosophila suzukii & Diptera & & 133 \\
\hline Sout American leaf miner & Liriomyza huidobrensis & Diptera & & 13 \\
\hline Blotch leaf miner & Nemorimyza maculosa & Diptera & & 2 \\
\hline Eastern Cherry Fruit Fly & Rhagoletis cingulata & Diptera & & 23 \\
\hline Black cherry fruit fly & Rhagoletis fausta & Diptera & & 1 \\
\hline Blueberry Maggot & Rhagoletis mendax & Diptera & & 2 \\
\hline
\end{tabular}




\begin{tabular}{|c|c|c|c|c|}
\hline papaya fruit fly & Toxotrypana curvicauda & Diptera & & 6 \\
\hline Guava fruit fly & Anastrepha striata & Diptera & & 18 \\
\hline Carambola Fruit Fly & Bactrocera carambolae & Diptera & & 109 \\
\hline Asian fruit fly & Bactrocera invadens & Diptera & & 230 \\
\hline Mediterranean fruit fly, Medfly & Ceratitis capitata & Diptera & & 199 \\
\hline Vegetable leaf miner & Liriomyza sativae & Diptera & & 38 \\
\hline American serpentine leafminer & Liriomyza trifolii & Diptera & & 12 \\
\hline Apple Maggot & Rhagoletis pomonella & Diptera & & 23 \\
\hline European Crane Fly & Tipula paludosa & Diptera & & 129 \\
\hline Olive Fruit Fly & Bactrocera oleae & Diptera & & 107 \\
\hline Peach fruit fly & Bactrocera zonata & Diptera & & 42 \\
\hline Oriental fruit fly & Bactrocera dorsalis & Diptera & & 645 \\
\hline Caribbean Fruit Fly; Carib Fly & Anastrepha suspensa & Diptera & & 2 \\
\hline Fruit fly & Bactrocera pyrifoliae & Diptera & na & \\
\hline Swede Midge & Contarinia nasturtii & Diptera & & 3 \\
\hline South American Rice Miner & Hydrellia wirthi & Diptera & na & \\
\hline Western Cherry Fruit Fly & Rhagoletis indifferens & Diptera & na & \\
\hline Canadian larch cone fly & Strobilomyia viaria & Diptera & na & \\
\hline Orange spiny whitefly & Aleurocanthus spiniferus & Hemiptera & & 1 \\
\hline Soybean Aphid & Aphis glycines & Hemiptera & & 205 \\
\hline Elm Seed Bug & Arocatus melanocephalus & Hemiptera & & 1 \\
\hline Bagrada Bug & Bagrada hilaris & Hemiptera & & 29 \\
\hline Japanese Wax Scale & Ceroplastes japonicus & Hemiptera & & 31 \\
\hline Cypress aphid & Cinara cupressi & Hemiptera & & 18 \\
\hline Asian citrus psyllid & Diaphorina citri & Hemiptera & & 10 \\
\hline Russian Wheat Aphid (RWA) & Diuraphis noxia & Hemiptera & & 129 \\
\hline Glassy-winged Sharpshooter & Homalodisca vitripennis & Hemiptera & & 6 \\
\hline Spotted Lanternfly & Lycorma delicatula & Hemiptera & & 7 \\
\hline Hibiscus (Pink) Mealybug & Maconellicoccus hirsutus & Hemiptera & & 3 \\
\hline Bean Plataspid & Megacopta cribraria & Hemiptera & & 47 \\
\hline Sugarcane spotted aleyrodid & Neomaskellia bergii & Hemiptera & & 1 \\
\hline San Jose scale & Quadraspidiotus perniciosus & Hemiptera & & 2 \\
\hline Pine Tortoise Scale & Toumeyella parvicornis & Hemiptera & & 2 \\
\hline Brown Citrus Aphid & Toxoptera citricidus & Hemiptera & & 8 \\
\hline Arrowhead Scale & Unaspis yanonensis & Hemiptera & & 8 \\
\hline Green scale & Coccus viridis & Hemiptera & & 5 \\
\hline Vine Mealybug & Planococcus ficus & Hemiptera & & 6 \\
\hline Brown Marmorated Stink Bug & Halyomorpha halys & Hemiptera & & 37 \\
\hline Hemlock Woolly Adelgid & Adelges tsugae & Hemiptera & & 150 \\
\hline Sweetpotato Whitefly (SPWf) & Bemisia tabaci & Hemiptera & & 918 \\
\hline Grass Sharpshooter & Draeculacephala minerva & Hemiptera & & 1 \\
\hline Blue-green Sharpshooter & Graphocephala atropunctata & Hemiptera & & 16 \\
\hline Mealybug & Hypogeococcus pungens & Hemiptera & & 1 \\
\hline Coffee Mealybug & Planococcus lilacinus & Hemiptera & & 1 \\
\hline Passionvine Mealybug & Planococcus minor & Hemiptera & & 2 \\
\hline Blue grey fly & Aleurocanthus woglumi & Hemiptera & na & \\
\hline Psyllid & Bactericera cockerelli & Hemiptera & na & \\
\hline
\end{tabular}


Soft Wax Scale

Iceryine Scale

Cocoa Mealybug

Elongate Hemlock Scale

Coconut red scale

Pallid cane leafhopper

Egyptian fluted scale

Cottony Cushion Scale

Ussuri oystershell scale

Paddy bug

Brown Chilean leaf-footed bug

Japanese maple scale

Margarodid

Grape ground pearl

Ground pearl

Wheat Bug

Cotton seed bug

Lobate Lac Scale

Black Parlatoria Scale

Cassava mealybug

Euphorbia Pit Scale

White Peach Scale

Cottony Citrus Scale

Mealybug

White-banded elm leafhopper

Rice Stinkbug

Twospotted Citrus Psyllid

Citrus snow scale

Grapevine phylloxera

Red-headed sharpshooter

European Pine Sawfly

Sirex Wasp

Giant Wood Wasp

Chestnut gall wasp

Green Alder Sawfly

Tremex Woodwasp

Scarlet Oak Sawfly

Horned Oak Gall Wasp

Erythrina Gall Wasp

Blue-black horntail
Ceroplastes destructor

Crypticerya multicicatrices

Exallomochlus hispidus

Fiorinia externa

Furcaspis oceanica

Haplaxius crudus

Icerya aegyptiaca

Icerya purchasi

Lepidosaphes ussuriensis

Leptocorisa acuta

Leptoglossus chilensis

Lopholeucaspis japonica

Margarodes prieskaensis

Margarodes vitis

Margarodes vredendalensis

Nysius huttoni

Oxycarenus Hyalinipennis

Paratachardina pseudolobata

Parlatoria ziziphi

Phenococcus manihoti

Planchonia stentae

Pseudaulacaspis pentagona

Pulvinaria polygonata

Ripersiella hibisci

Scaphoideus luteolus

Tibraca limbativentris

Trioza erytreae

Unaspis citri

Viteus vitifoliae

Xyphon fulgidum

Neodiprion sertifer

Sirex noctilio

Urocerus gigas

Dryocosmus kuriphilus

Monsoma pulveratum

Tremex fuscicornis

Caliroa quercuscoccineae

Callirhytis cornigera

Quadrastichus erythrinae

Sirex ermak

Western black-headed bud wo Acleris gloverana

Eastern black-headed budworr Acleris variana

Leek Moth

Black Cutworm (BCw)

Fruit Tree Tortrix

Cherry Blossom Moth

Polyphagous leaf roller
Acrolepiopsis assectella

Agrotis ipsilon

Archips podana

Argyresthia pruniella

Argyrotaenia ljungiana
Hemiptera

Hemiptera na

Hemiptera na

Hemiptera na

Hemiptera na

Hemiptera na

Hemiptera 1

Hemiptera

Hemiptera

na

Hemiptera

7

Hemiptera

3

Hemiptera na

Hemiptera na

Hemiptera na

Hemiptera

4

Hemiptera na

Hemiptera

Hemiptera

5

Hemiptera

Hemiptera

14

Hemiptera

Hemiptera

Hemiptera

Hemiptera

Hemiptera

Hemiptera

Hemiptera

Hemiptera

Hemiptera

Hymenoptera

Hymenoptera

Hymenoptera

Hymenoptera

Hymenoptera

Hymenoptera

Hymenoptera

Hymenoptera

Hymenoptera

Hymenoptera

1

Lepidoptera

Lepidoptera

118

Lepidoptera

Lepidoptera

130

Lepidoptera

Lepidoptera 
Silver Y Moth

Cactus Moth

Geranium bronze

Peach Fruit Moth

Large aspen tortrix

Eastern spruce budworm

The oblique banded leaf roller

Golden Twin Spot Moth

Cocoa pod borer

Hickory Shuckworm (HSw)

Codling Moth (CM)

Nut fruit tortix

Nettle Caterpillar

Pine-tree Lappet

Sakhalin Silk Moth

Yellow peach moth

Zimmerman Pine Moth

European Pepper Moth

Onion carpenter worm

Spotted bollworm - cotton

Cherry Bark Tortrix

Light Brown Apple Moth

Mottled Umber Moth

Fruit Piercing Moth

European Grape Berry Moth

Plum fruit moth

European Poplar Shoot Borer

Corn earworm

Fall Webworm

Tomato Pinworm

Brinjal Fruit and Shoot Borer

na

na

Satin Moth

European Grapevine Moth

Okinawa gypsy moth

Asian Gypsy Moth

Nun Moth

Hokkaido gypsy moth

Iris Borer

Eastern tent caterpillar

Forest Tent Caterpillar

Sweetpotato vine borer

Winter Moth

Douglas-fir tussock moth

Asian Corn Borer

European Corn Borer
Autographa gamma

Cactoblastis cactorum

Cacyreus marshalli

Carposina sasakii

Choristoneura conflictana

Choristoneura fumiferana

Choristoneura rosaceana

Chrysodeixis chalcites

Conopomorpha cramerella

Cydia caryana

Cydia pomonella

Cydia splendana

Darna pallivitta

Dendrolimus pini

Dendrolimus superans

Dichocrocis punctiferalis

Dioryctria zimmermani

Duponchelia fovealis

Dyspessa ulula

Earias vittella

Enarmonia formosana

Epiphyas postvittana

Erannis defoliaria

Eudocima fullonia

Eupoecilia ambiguella

Grapholita funebrana

Gypsonoma aceriana

Helicoverpa zea

Hyphantria cunea

Keiferia lycopersicella

Leucinodes africensis

Leucinodes pseudorbonalis

Leucinodes rimavallis

Leucoma salicis

Lobesia botrana

Lymantria albescens

Lymantria dispar

Lymantria monacha

Lymantria umbrosa

Macronoctua onusta

Malacosoma americanum

Malacosoma disstria

Omphisa anastomosalis

Operophtera brumata

Orgyia pseudotsugata

Ostrinia furnacalis

Ostrinia nubilalis
Lepidoptera

Lepidoptera 9

Lepidoptera 14

Lepidoptera 82

Lepidoptera 316

Lepidoptera 111

Lepidoptera 157

Lepidoptera 11

Lepidoptera 106

Lepidoptera 13

Lepidoptera $\quad 141$

Lepidoptera 11

Lepidoptera 1

Lepidoptera 28

Lepidoptera 24

Lepidoptera 1

Lepidoptera 1

Lepidoptera 3

Lepidoptera 1

Lepidoptera 7

Lepidoptera 3

Lepidoptera 1433

Lepidoptera 29

Lepidoptera 7

Lepidoptera 6

Lepidoptera 14

Lepidoptera 31

Lepidoptera 165

Lepidoptera 152

Lepidoptera 1

Lepidoptera 28

Lepidoptera 1

Lepidoptera 2

Lepidoptera 77

Lepidoptera 1

Lepidoptera 14

Lepidoptera 343

Lepidoptera 85

Lepidoptera 21

Lepidoptera 8

Lepidoptera 46

Lepidoptera $\quad 116$

Lepidoptera 1

Lepidoptera 379

Lepidoptera 172

Lepidoptera 29

Lepidoptera 74 
Spring Cankerworm

Chestnut leafroller

Stalk Borer

Palm moth

Pink bollworm - cotton

Pink-spotted bollworm

Poinciana Looper

Potato Tuberworm

Large White Butterfly - brassic Pieris brassicae

European Pine Shoot Moth(EP Rhyacionia buoliana

Southern armyworm

Egyptian Cottonworm

Cotton Cutworm

Western Bean Cutworm

Red-belted Clearwing

False codling moth

Green Oak Tortrix

Tomato Leaf Miner

Apple Ermine Moth (AEM)

Mexican Rice Borer

Oriental Fruit Moth (OFM)

Old World Bollworm - cotton

Bean butterfly

Soybean Pod Borer

Pear leaf blister moth

Rosy Gypsy Moth

Squash Vine Borer

Tomato Fruit Borer

Bruce Spanworm

Tufted Apple Bud

Fall Armyworm

Oak Processionary Moth

Summer fruit tortrix moth

Asiatic Rice Borer

Yellow Peach Moth; Castor Car Conogethes punctiferalis

Hemlock Looper

Lime Swallowtail

Legume pod borer

Eggplant borer

Pecan Nut Casebearer

Apple Tortrix

Variegated Golden Tortrix

Carnation Leaf Roller

Leafroller

Peach fruit moth

Carpenter Worm

Western Spruce Budworm
Paleacrita vernata

Pammene fasciana

Papaipema nebris

Paysandisia archon

Pectinophora gossypiella

Pectinophora scutigera

Pericyma cruegeri

Phthorimaea operculella

Spodoptera eridania

Spodoptera littoralis

Spodoptera litura

Striacosta albicosta

Synanthedon myopaeformis

Thaumatotibia leucotreta

Tortrix viridana

Tuta absoluta

Yponomeuta malinellus

Eoreuma loftini

Grapholita molesta

Helicoverpa armigera

Lampides boeticus

Leguminivora glycinivorella

Leucoptera malifoliella

Lymantria mathura

Melittia cucurbitae

Neoleucinodes elegantalis

Operophtera bruceata

(TABM Platynota idaeusalis

Spodoptera frugiperda

Thaumetopoea processionea

Adoxophyes orana

Chilo suppressalis

Lambdina fiscellaria

Papilio demoleus

Maruca vitrata

Leucinodes orbonalis

Acrobasis nuxvorella

Archips fuscocupreanus

Archips xylosteanus

Cacoecimorpha pronubana

Capua tortrix

Carposina niponensis

Chilecomadia valdiviana

Choristoneura freemani
Lepidoptera 85

Lepidoptera 5

Lepidoptera 16

Lepidoptera 2

Lepidoptera 20

Lepidoptera 3

Lepidoptera 5

Lepidoptera 12

Lepidoptera 78

Lepidoptera 5

Lepidoptera 41

Lepidoptera 26

Lepidoptera 80

Lepidoptera 7

Lepidoptera 4

Lepidoptera 36

Lepidoptera 11

Lepidoptera 34

Lepidoptera 18

Lepidoptera 8

Lepidoptera 56

Lepidoptera 433

Lepidoptera 126

Lepidoptera 17

Lepidoptera 5

Lepidoptera 41

Lepidoptera 3

Lepidoptera 4

Lepidoptera 350

Lepidoptera 242

Lepidoptera 6

Lepidoptera 7

Lepidoptera 23

Lepidoptera 57

Lepidoptera 202

Lepidoptera 566

Lepidoptera 33

Lepidoptera 633

Lepidoptera 159

Lepidoptera 6

Lepidoptera 21

Lepidoptera na

Lepidoptera 25

Lepidoptera na

Lepidoptera na

Lepidoptera

Lepidoptera

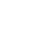

(a)

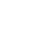

(2)

7

4

(1)

11

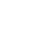

8

6

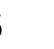

5

4

42

6

(3)

3

7

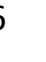

21




Cabbage Cluster Caterpillar
Bud Borer
Manchurian fruit moth
Cherry fruitworm
Lesser appleworm
Siberian coniferous silk moth
Walnut moth
White-winged gypsy moth
Mountain tent caterpillar
Pear fruit moth
Banana Moth
Citrus pock caterpillar
Avocado seed moth
Potato tuber moth
Mormon Cricket
Southern Mole Cricket
Grasshopper
Pear Thrips
South African citrus thrips
California citrus thrips
Rice Thrips
European Flower Thrips
Western flower thrips
Melon Thrips
Chilli Thrips; Yellow Tea Thrips
Thrips
Myoporum thrips
Fruit tree spider mite
Chile false red mite of grapes
Titchi mite
Cassava mite
Fuchsia gall mite
Titrus brown mite
Twid mite
Motted Spider Mite

\section{Pests identified to genus only}

Scarab beetles

Longhorned Beetle

lily weevils

Weevils

Bromeliad weevils

Cerambycid Sawyer Beetle

May-June beetles

Popillia beetles

Wood-borers

Cerambycid Beetle
Crocidolomia binotalis

Crocidosema aporema

Cydia inopinata

Cydia packardi

Cydia prunivora

Dendrolimus sibiricus

Erschoviella musculana

Lymantria postalba

Malacosoma parallela

Numonia pyrivorella

Opogona sacchari

Prays endocarpa

Stenoma catenifer

Tecia solanivora

Anabrus simplex

Scapteriscus borellii

Trimerotropis fratercula

Taeniothrips inconsequens

Scirtothrips aurantii

Scirtothrips citri

Stenchaetothrips biformis

Frankliniella intonsa

Frankliniella occidentalis

Thrips palmi

Scirtothrips dorsalis

Haplothrips chinensis

Klambothrips myopori

Amphitetranychus viennensis

Brevipalpus chilensis

Eriophyes litchii

Mononychellus tanajoa

Aculops fuchsiae

Eutetranychus orientalis

Oligonychus perditus

Tetranychus evansi

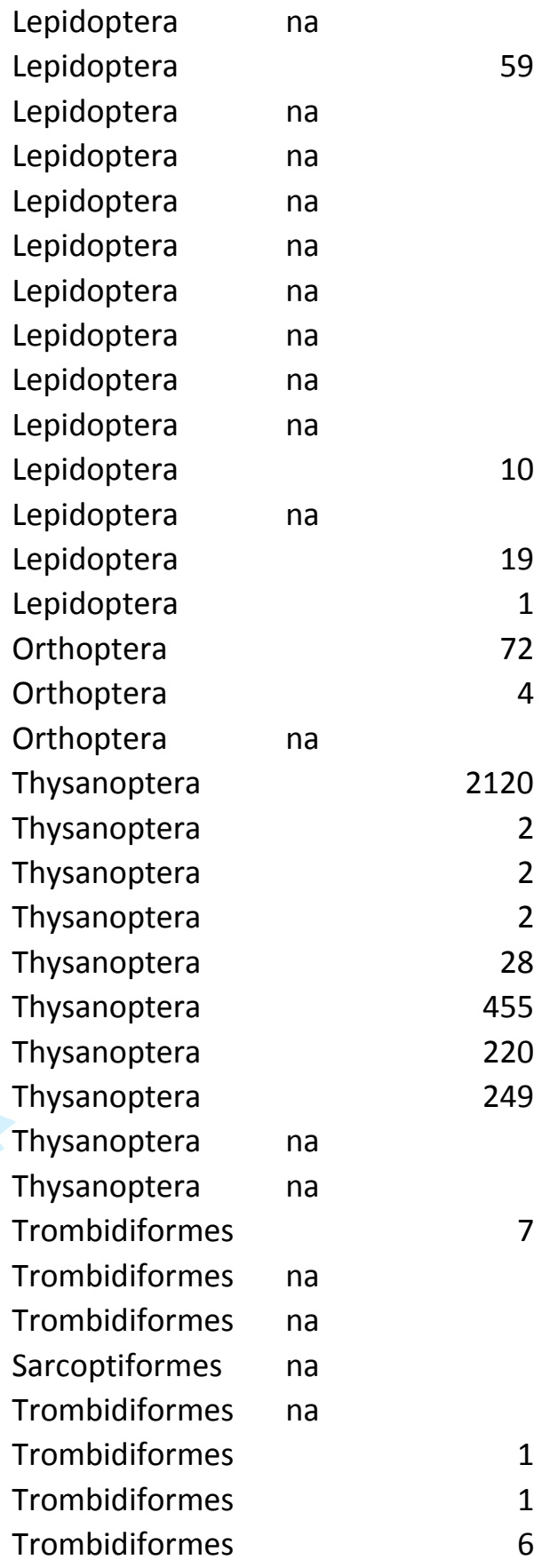

Coleoptera

Coleoptera

Coleoptera

Coleoptera

Coleoptera

Coleoptera

Coleoptera

Coleoptera

Coleoptera

Coleoptera

\section{0}

19

4

$\begin{array}{ll}\text { Adoretus spp. } & \text { Coleoptera } \\ \text { Anoplophora spp. } & \text { Coleoptera } \\ \text { Brachycerus spp. } & \text { Coleoptera } \\ \text { Conotrachelus spp. } & \text { Coleoptera } \\ \text { Metamasius spp. } & \text { Coleoptera } \\ \text { Monochamus spp. } & \text { Coleoptera } \\ \text { Phyllophaga spp. } & \text { Coleoptera } \\ \text { Popillia spp. } & \text { Coleoptera } \\ \text { Xyleborus spp. } & \text { Coleoptera } \\ \text { Xylotrechus spp. } & \text { Coleoptera }\end{array}$




$\begin{array}{lll}\text { Old world fruit flies } & \text { Ceratitis spp. } & \text { Diptera } \\ \text { Fruit flies } & \text { Pterandrus spp. } & \text { Diptera } \\ \text { Cuckoo wasps } & \text { Chrysis spp. } & \text { Hymenoptera } \\ \text { Cuckcoo bees } & \text { Coelioxys spp. } & \text { Hymenoptera } \\ \text { Noctuid Moth } & \text { Copitarsia spp. } & \text { Lepidoptera } \\ \text { Seed worms } & \text { Cydia spp. } & \text { Lepidoptera } \\ \text { Red Pine Shoot Moths } & \text { Dioryctria spp. } & \text { Lepidoptera } \\ \text { Tortricid moths } & \text { Proeulia spp. } & \text { Lepidoptera }\end{array}$

Arthropod pest species not included in the five pest databases

\begin{tabular}{|c|c|c|}
\hline Kanzawa spider mite & Tetranychus kanzawai & Trombidiformes \\
\hline NA & Tetranychus parakanzawai & Trombidiformes \\
\hline Bark beetle & Crypturgus subcribrosus & Coleoptera \\
\hline Bark beetle & Crypturgus hispidulus & Coleoptera \\
\hline Hairy spruce bark beetle & Dryocoetes autographus & Coleoptera \\
\hline Bark beetle & Dryocoetes hectographus & Coleoptera \\
\hline Engraver beetle & Ips acuminatus & Coleoptera \\
\hline Bark beetle & Orthotomicus suturalis & Coleoptera \\
\hline Striped Ambrosia Beetle & Trypodendron lineatum & Coleoptera \\
\hline Fruit-tree pinhole borer & Xyleborinus saxeseni & Coleoptera \\
\hline Ambrosia beetle & Xyleborus affinis & Coleoptera \\
\hline Wireworm & Hypnoidus bicolor & Coleoptera \\
\hline Yellow toadflax stem weevil & Mecinus janthinus & Coleoptera \\
\hline Coffee berry borer & Hypothenemus hampei & Coleoptera \\
\hline Hessian fly & Mayetiola destructor & Diptera \\
\hline African fig fly & Zaprionus indianus & Diptera \\
\hline Blueberry gall midge & Dasineura oxycoccana & Diptera \\
\hline Glasshouse Striped Sciarid & Bradysia ocellaris & Diptera \\
\hline Citrus mealybug & Planococcus citri & Hemiptera \\
\hline Solenopsis mealybug & Phenacoccus solenopsis & Hemiptera \\
\hline Apple mealybug & Phenacoccus aceris & Hemiptera \\
\hline Matsumoto mealybug & Crisicoccus matsumotoi & Hemiptera \\
\hline Cyanotis scale & Aspidiotus excises & Hemiptera \\
\hline Mottled arum aphid & Neomyzus circumflexus & Hemiptera \\
\hline Leaf curl plum aphid & Brachycaudus helichrysi & Hemiptera \\
\hline Cabbage aphid & Brevicoryne brassicae & Hemiptera \\
\hline Asian sowthistle aphid & Hyperomyzus carduellinus & Hemiptera \\
\hline Aphid & Toxoptera aurantii & Hemiptera \\
\hline Bronze bug & Thaumastocoris peregrinus & Hemiptera \\
\hline Grapewine leafminer & Antispila hydrangaeella & Lepidoptera \\
\hline Leaf worm & Copitarsia decolora & Lepidoptera \\
\hline NA & Lymantria sinica & Lepidoptera \\
\hline Beet armyworm & Spodoptera exigua & Lepidoptera \\
\hline Paddy armyworm & Spodoptera mauritia & Lepidoptera \\
\hline Onion thrips & Thrips tabaci & Thysanoptera \\
\hline Black flower thrips & Haplothrips reuteri & Thysanoptera \\
\hline
\end{tabular}




\begin{tabular}{|c|c|}
\hline \multicolumn{2}{|l|}{ na = not available) } \\
\hline Number of BINs & BIN code \\
\hline & 1 ACB6359 \\
\hline & 1 AAZ0928 \\
\hline & 1 AAP5743 \\
\hline & 1 AAE6821 \\
\hline & 1 AAO3421 \\
\hline & 1 AAL5975 \\
\hline & 1 AAL6427 \\
\hline & 1 AAC5728 \\
\hline & 1 ACD3954 \\
\hline & 1 AAJ8840 \\
\hline & 1 ACO5038 \\
\hline & 1 AAF8687 \\
\hline & 1 AAL7691 \\
\hline & 1 ABA6367 \\
\hline & 1 ACG1093 \\
\hline & 1 ABX2319 \\
\hline & 1 AAA7915 \\
\hline & 1 AAA5673 \\
\hline & 1 AAE7566 \\
\hline & 1 AAF8473 \\
\hline & 1 AAD4999 \\
\hline & 1 ABA9101 \\
\hline 1 & 1 ACD6019 \\
\hline & 1 ACD6123 \\
\hline & 1 AAU7332 \\
\hline & $1 \mathrm{AAO} 2348$ \\
\hline & 1 ААК3643 \\
\hline & 1 AAM9608 \\
\hline & 1 AAW8984 \\
\hline & 1 AAC0432 \\
\hline 1 & $1 \mathrm{AAO} 1465$ \\
\hline & $1 \mathrm{ACl} 2251$ \\
\hline & 1 ACD8272 \\
\hline & 1 AAX4387 \\
\hline & 1 AAE2308 \\
\hline 1 & 1 ACS9826 \\
\hline & 1 AAX4767 \\
\hline & 1 AAA9568 \\
\hline 1 & 1 ACA8527 \\
\hline & 1 ACD2221 \\
\hline & $1 \mathrm{ACH} 5975$ \\
\hline 1 & 1 AAM7726 \\
\hline & 1 ABW3885 \\
\hline & 1 ACW0577 \\
\hline & 1 AAY3807 \\
\hline
\end{tabular}

https://mc06.manuscriptcentral.com/genome-pubs 


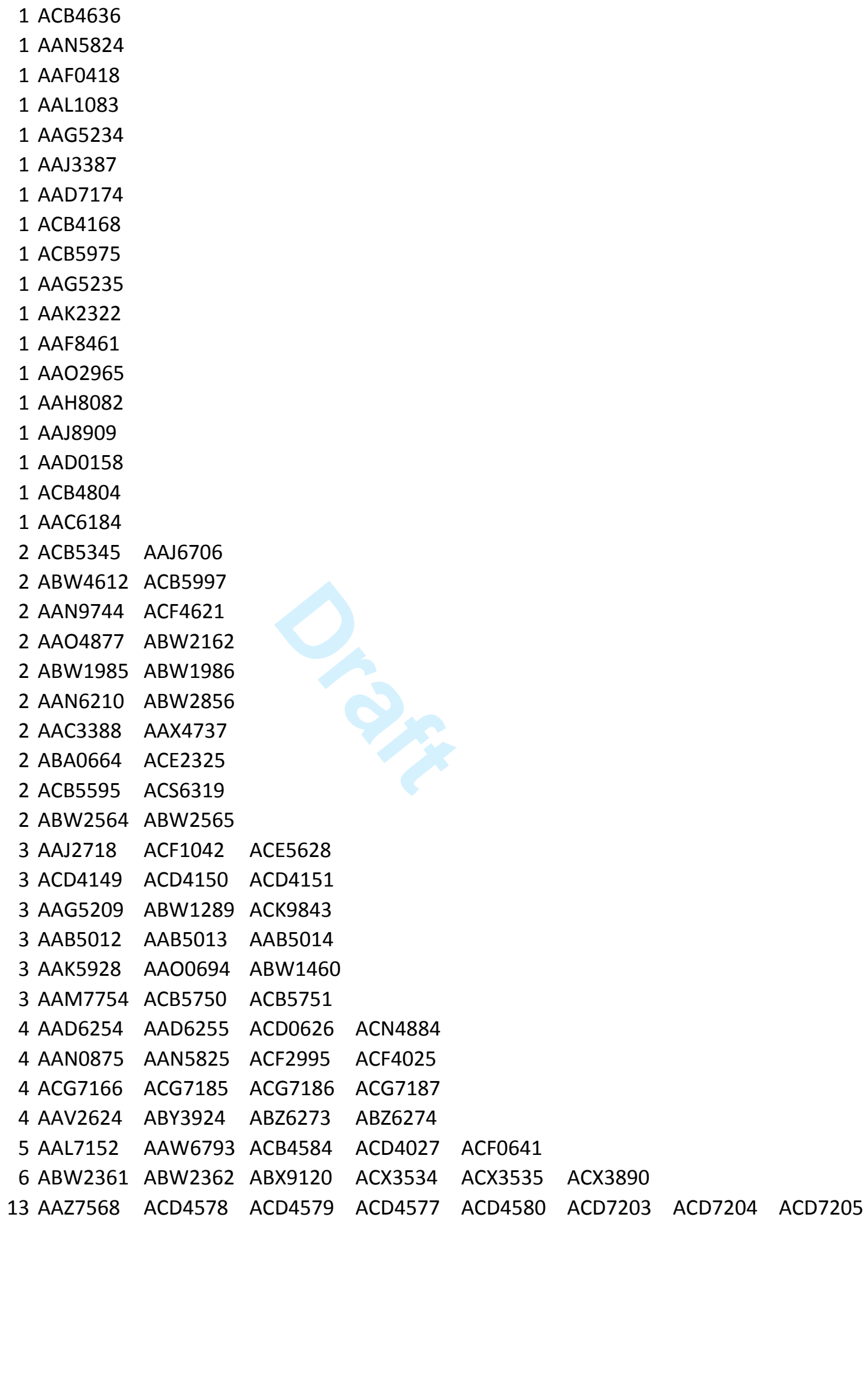


na

na

2

2

1

1

1

1

1

1

1

2

1

2

1

1

1

https://mc06.manuscriptcentral.com/genome-pubs 
na

2

1

2

1 AAE5912

1 AAJ2068

1 AAC0699

1 AAF3739

1 AAA2296

1 AAC1495

1 AAD3172

1 AAA5439

1 AAA2296

1 AAB9956

1 ACD2253

1 ACP5553

1 ACP5553

1 ACP5553

1 AAB2814

1 ACI0768

1 AAB6024

1 AAC2003

1 AAC2499

1 AAD8670

1 ABA6469

1 AAC 9720

1 AAL1148

1 AAD5604

https://mc06.manuscriptcentral.com/genome-pubs 


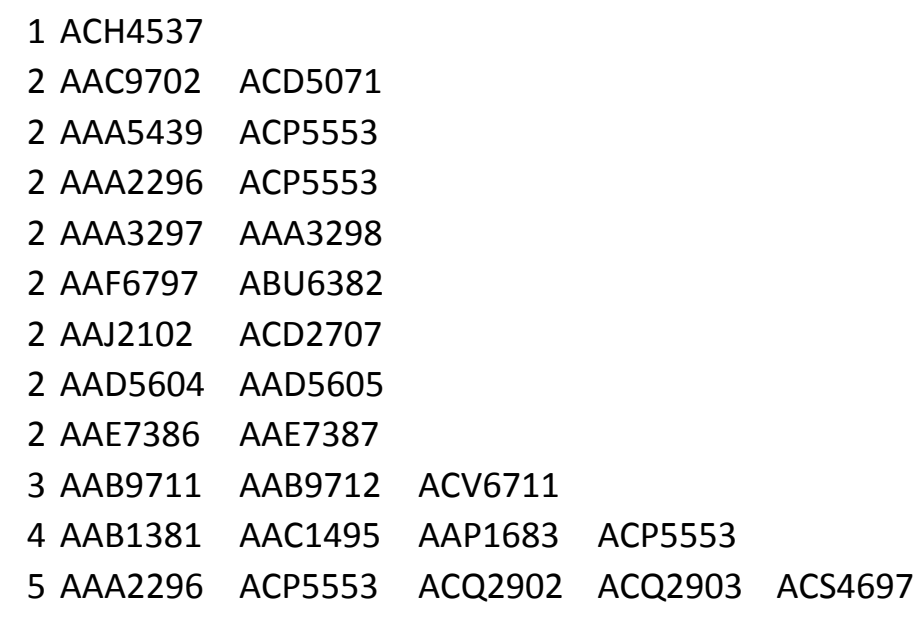

na

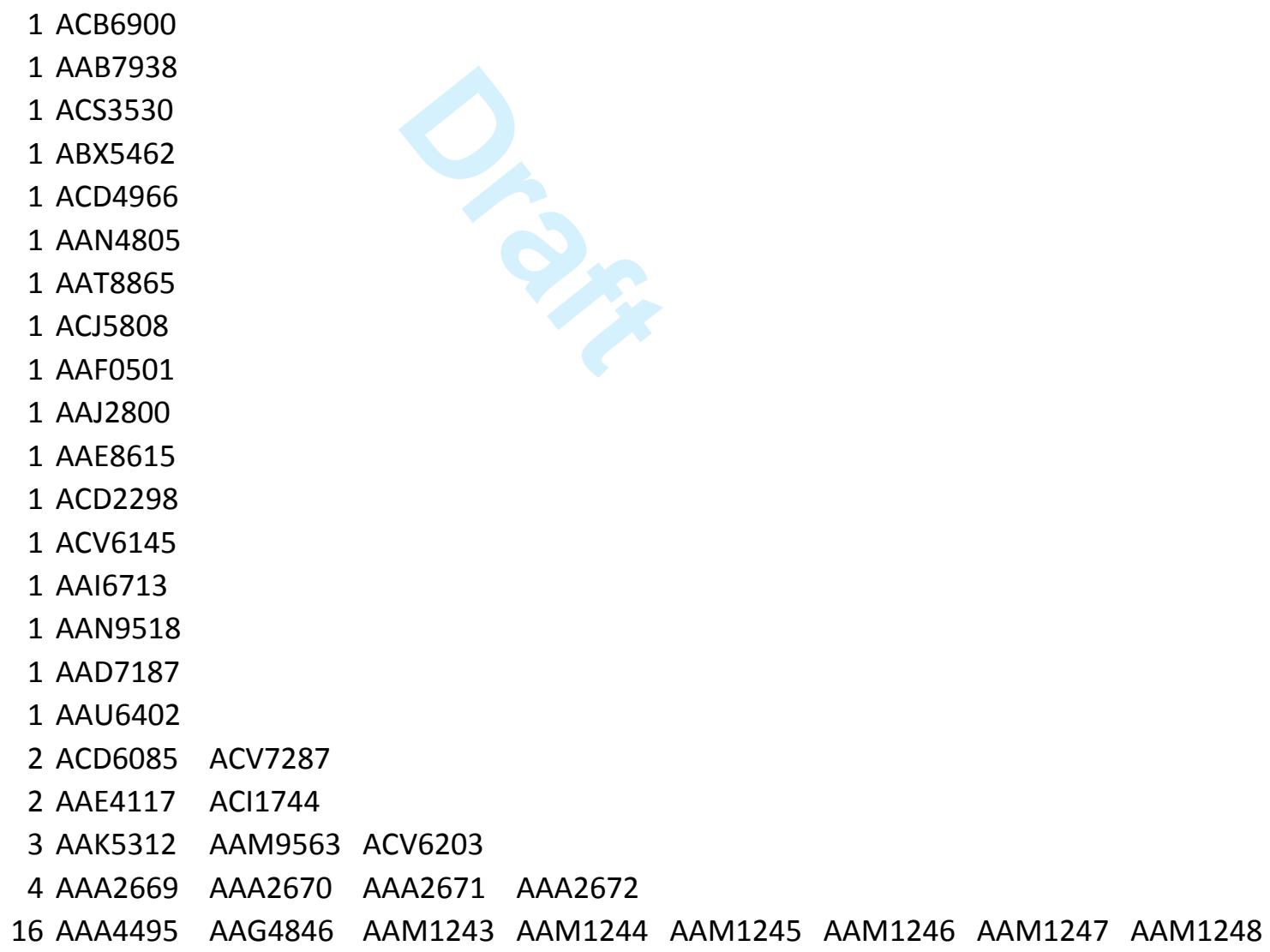


na

1

2

1

1

1

4

1

2

1 ACQ5023

1 AAB8469

1 AAF8342

2 AAY0230 ACD3968

2 AAX4442 ACM6242

2 ACB7411 AAZ8297

1

1 AAA6716

1 AAA5320

1 AAB4903

1 AAA3364

1 AAB5839

1 AAC2750

1 AAA2955

https://mc06.manuscriptcentral.com/genome-pubs 
1 AAB4345

1 AAA7177

1 AAC0302

1 ACB4958

1 AAA3301

1 ABX5883

1 AAA1517

1 AAB3384

1 AAA4000

1 AAA7282

1 AAA3532

1 AAC0640

1 AAJ4608

1 AAB6845

1 AAB6845

1 AAC8071

1 AAB4478

1 ACR7868

1 AAM 4530

1 AAD0545

1 AAC5227

1 AAB0679

1 AAB4418

1 AAC5182

1 AAD8039

1 AAB9236

1 AAB0379

1 ABZ5815

1 AAA2435

1 AAK4075

1 AAE7333

1 ACM 4472

1 ACS3950

1 AAA5528 ACD7806

1 ACD8827

1 AAC4957

1 AAA2052

1 AAA5537

1 AAA2052

1 AAD1618

1 AAA6548

1 AAA4130

1 ACD7464

1 AAA3963

1 AAE5045

1 ACE3275

1 AAA2654

AAA2436

https://mc06.manuscriptcentral.com/genome-pubs 
1 AAA4433

1 AAC8302

1 ACF1624

1 AAL3637

1 AAH4802

1 AAX1708

1 AAC0387

1 AAB9396

1 AAB0552

1 AAD1611

1 AAA6521

1 ACE4947

1 AAA8626

1 AAF3338

1 AAC4688

1 AAE7729

1 AAC2506

1 AAJ8033

1 AAA7740

2 AAL6887 ACS2942

2 AAB0523 ACS0456

2 AAA5223 ACS4718

2 AAA3848 AAA3849

2 ACQ6703 ACQ6704

2 AAK9162 ACD4054

2 AAB0845 ACS1452

2 AAK7015 ACF2087

2 AAA0476 AAN6936

2 AAA2999 AAA3000

2 AAA5192 ABY7901

2 AAA4532 ACE4783

2 ABV0114 ACH4173

3 AAD8062 ABA2177

3 АAB0666

3 AAC8071

3 AAA5482

3 AAD6030

4 AAA0257

6 AAE7334 1

1

3

4

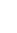

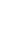

ABY6932

ACV6760

AAD8750 AAO4234

ACE9385 ACE9387

AAD6031 ACA1681

AAB2755 AAB2756 AAD9057

AAO2620 ABA8540 ACH6349 ACV6559 ACV8800

\footnotetext{
https://mc06.manuscriptcentral.com/genome-pubs
} 
5

1

3 AAJ2390 ACA6391 ACA6392

2

1 ACC0651

2 AAI0797 AAI0798

2 AAI0768 AAI0769

2 AAT9983 ACI0102

3 AAF6737 AAN4977 ACD6098

4 AAB8717 AAM5263 ACB4865 ACX8955

4 AAE7913 AAM8085 AAN2747 ACI0120

12 AAC9747 AAC9748 AAC9749 AAC9750 AAC9751 ACQ0434 ACQ0435 ACQ4218

1 ACQ0009

2 ACB5670 ACB5671 
ACD7206 ACD7474 ACD7547 ACE8205 ACF4217 
AAT8875 ACB7300 ACD4214 ACD5051 ACN1674 ACR3284 ACV2709 ACV2710 
ACV6509 ACV6510 ACV6511 ACV7644 